\title{
Revision of the costata-group of Alona s. lato (Cladocera: Anomopoda: Chydoridae) confirms its generic status
}

\author{
Artem Y. SINEV ${ }^{1, *} \&$ Henri J. DUMONT ${ }^{2}$ \\ ${ }^{1}$ Department of Invertebrate Zoology, Biological Faculty, Lomonosov Moscow State University, \\ Leninskie Gory, Moscow 119991, Russia and A.N. Severtsov Institute of Ecology and Evolution, \\ Leninsky Prospect 33, Moscow 119071, Russia. \\ ${ }^{2}$ Department of Ecology, Jinan University, Guangzhou 510632, China. \\ ${ }^{2}$ Department of Biology, Ghent University, 9000 Ghent, Belgium. \\ *Corresponding author: artemsinev@gmail.com \\ ${ }^{2}$ Email: $\underline{\text { Henri.Dumont@ugent.be }}$ \\ ${ }^{1}$ urn:1sid:zoobank.org:author:FBB6AAEF-4F83-4F43-B6C3-E50C150EA9FE \\ ${ }^{2}$ urn:lsid:zoobank.org:author:647CC682-C915-4855-B447-74575898B4CB
}

\begin{abstract}
By taking Flavalona gen. nov. out of Alona s.1. (Cladocera: Anomopoda: Chydoridae), the last major clade has now been removed from this polyphyletic assemblage. Flavalona gen. nov. is a monophylum defined by having three, rarely two connected head pores and slit-shaped, rarely rounded lateral head pores. Postabdomen rather long, distally narrowed, with robust marginal denticles and weakly developed lateral fascicles of setules. End-claw weakly curved and with short basal spine. Male postabdomen with gonopores opening at the end of a penis-like outgrowth. Trunk limbs: exopodite of P2 with seta; inner portion of P4 with flaming-torch shaped setae; P5 with filter plate of three setae; P6 a large simple lobe. The relationship of the new genus with other Aloninae remains to be determined. A key to the 11 species of the genus is provided and a discussion of their geographic distribution and habitat type is given.
\end{abstract}

Keywords. Cladocera, Alona, taxonomy, morphology, revision.

Sinev A.Y. \& Dumont H.J. 2016. Revision of the costata-group of Alona s. lato (Cladocera: Anomopoda: Chydoridae) confirms its generic status. European Journal of Taxonomy 223: 1-38. http://dx.doi.org/10.5852/ ejt.2016.223

\section{Introduction}

Species in the polyphyletic genus Alona Baird, 1843, historically the result of merging about a dozen of species groups, are similar in gross morphology by convergence (Van Damme \& Dumont 2008a, 2008b; Van Damme et al. 2010). Recent revisions of these groups have led to their assignment to a long series of genera (Dumont \& Silva-Briano 2000; Sinev 2004; Sinev \& Shiel 2008; Van Damme \& Dumont 2008a, 2009; Van Damme et al. 2009; Van Damme et al. 2011; Van Damme \& Sinev 2011; Van Damme $\&$ Maiphae 2013). Some groups were transferred to new, others to previously described but reinstated 
and/or redefined genera (Sinev et al. 2005; Sinev \& Kotov 2012), while Van Damme \& Dumont (2008b) restricted true Alona to the quadrangularis-group, now consisting of five species (Sinev 2012). With the assignment of the pulchella-group to Ovalona Van Damme \& Dumont, 2008 (Sinev 2015b), today only few clades of Alona s.l. remain unrevised.

The largest of these clades is the costata-group. It was outlined by Sinev (1999a, 2001, 2008, 2009) and is defined by the unique morphology of its lateral head pores (Sinev 1999a). They are slit-shaped, with pocket-like cavities below, and the length of the lateral pores and size of their pocket vary between species. Other distinctive features include a distally narrowing postabdomen with well-developed composite marginal denticles, armed with small spinules, and weakly developed lateral setule fascicles, IDL with three setae, the endite of limb four with a row of robust marginal setae, shaped as flamingtorches, a large limb VI shaped as a rounded lobe, and a penis-like process on the male postabdomen. According to Van Damme \& Dumont (2008a), the costata-clade is part of the Hexalona-branch of Alona s.l., a supra-generic category characterized by having six thoracic limbs and a full set of setae on each limb. All species of Hexalona have inner setae on endites 2-3 of limb I, seven setae on exopodite III, and filter plate $\mathrm{V}$ with three setae. A generic status for the costata-group was therefore suggested but not formally instated by Van Damme \& Dumont (2008a) and by Sinev (2008).

In recent years, the group has been intensively studied (Sinev 1999a, 2001, 2008, 2009; Kotov \& Sinev 2004; Van Damme et al. 2011; Van Damme \& Eggermont 2011; Sousa et al. 2015), and several new species have been described. Currently, it includes 11 species. Here, we formally raise it to the rank of a genus, and discuss the taxonomy and geographic ranges of all currently recognized species.

\section{Material and methods}

Animals and exuviae were selected from samples under a stereoscopic microscope, placed on slides (in a drop of a glycerol-formaldehyde mixture), and studied under a microscope in toto for identification and measurements. One to five specimens from each population were dissected for analysis of appendages. Measurements were conducted using an eyepiece-micrometer; all drawings were made with a camera lucida. We here use the system of enumeration for different setae on thoracic limbs proposed by Kotov et al. (2010) as for all Anomopoda.

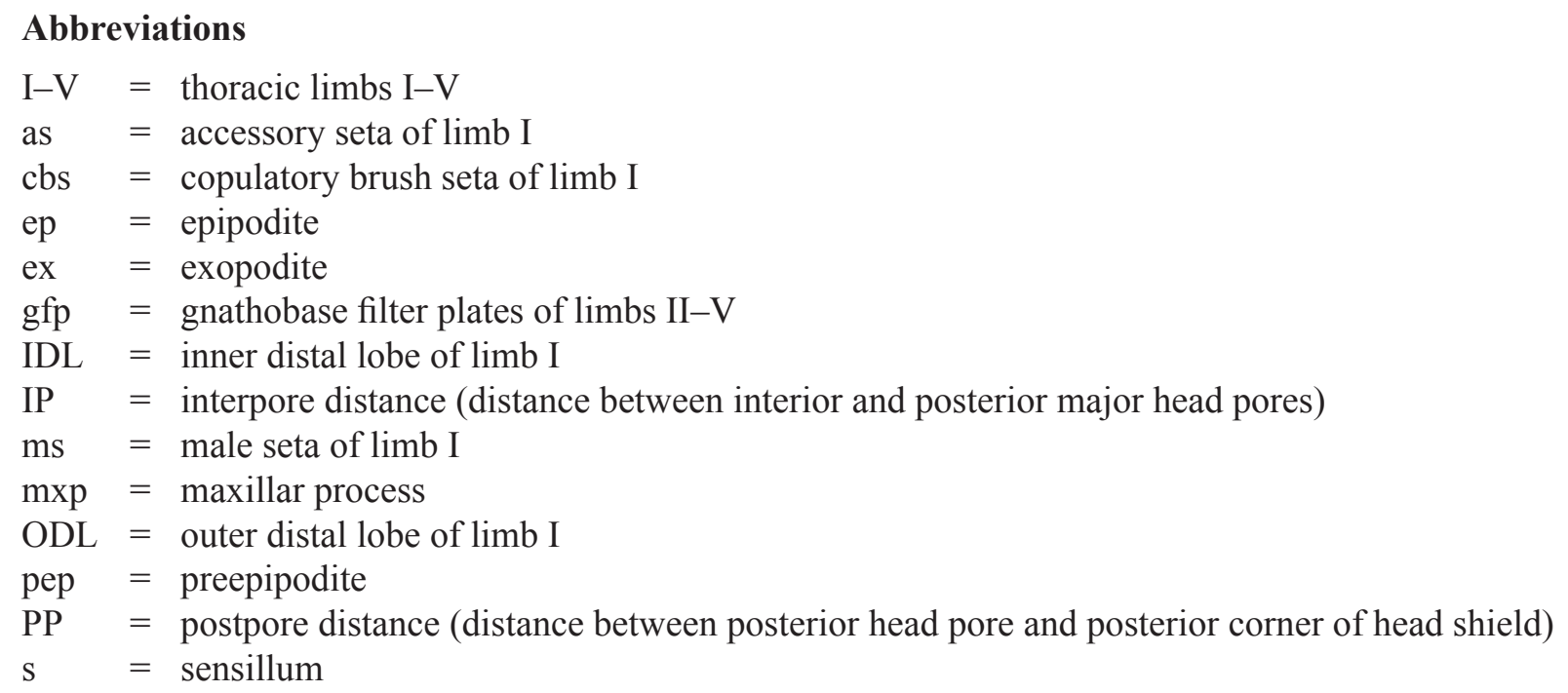




\title{
Results
}

\author{
Order Anomopoda Sars, 1865 \\ Family Chydoridae Dybowski \& Grochowski, 1894 emend. Frey 1967 \\ Subfamily Aloninae Dybowski \& Grochowski, 1894 emend. Frey 1967 \\ Tribe Alonini Dybowski \& Grochowski, 1894 emend. Kotov 2000 \\ Flavalona gen. nov. \\ urn:1sid:zoobank.org:act:8CC51B78-C807-4A31-8808-F167B8E5095A
}

\section{Type species}

Alona costata Sars, 1862.

\section{Diagnosis}

\section{Female}

Aloninae of moderate size, maximum length of adult female $0.5-0.7 \mathrm{~mm}$. Body oval, of moderate height, compressed laterally. Maximum height usually at mid-body. Valves and head shield without keel, valves from previous molts sometimes retained. Dorsal, posterior and ventral margins of valves evenly curved, postero-dorsal, postero-ventral angles and anterior-ventral angles of valves broadly rounded. Posteroventral angle of valves without denticles. Valves with moderately to well-developed linear sculpture or tubercles.

Head small, triangular to round in lateral view, rostrum short, pointing downward. Eye larger than ocellus. Head shield broad, with broadly rounded rostrum. Posterior margin of head shield usually broadly rounded. Three, in one species two, main head pores, narrowly connected. Lateral head pores transverse slits (rounded in F. sphagnophila (Van Damme \& Eggermont, 2011)), with flattened pocketlike cavities below. Labrum with moderately broad keel, keel apex rounded, posterior margin of keel with two small clusters of setae.

Thorax 1.5 times longer than abdomen.

Abdomen without abdominal joint, middle abdominal segment not saddle-shaped.

Postabdomen moderately long, narrowing distally in postanal part. Ventral margin straight. Basis of claws bordered from distal margin by clear incision. Distal margin straight or convex, distal angle usually acute, with rounded tip. Dorsal margin concave in anal portion, straight in postanal portion. Preanal angle well-defined, postanal angle weakly-defined. Postanal margin with well-developed composite marginal denticles with spines at anterior margin. Lateral fascicles of setules narrow, weakly developed, distalmost setules in fascicles not thicker than others, shorter than marginal denticles. Postabdominal claw of moderate length, weakly curved. Basal spine short.

Antennule not protruding beyond the tip of rostrum, with 3-4 transverse rows of short setules on anterior surface. Antennular seta thin. Nine terminal aesthetascs of variable length.

Antenna with antennal formula setae $0-0-3 / 1-1-3$, spines $1-0-1 / 0-0-1$. Basal segment robust, branches elongated, all segments narrow, cylindrical, basal segment of each branch 1.5 times longer than two others. Seta of basal segment of endopodite not reaching end of endopodite. Seta of middle segment of endopodite and apical setae of same morphology, similar length and thickness. Antennal spines well developed.

Six pairs of thoracic limbs. 
LimB I. With accessory seta. IDL with 3 setae, seta 1 short, setae 2 and 3 of similar size, armed with thin setules in distal portion. Endite 3 with four setae. Endite 2 with three outer setae and short inner seta. Endite 1 with two 2-segmented setae, shortened, stub-like flat seta, and inner seta longer than inner seta of endite 2. Ventral surface of limb with rows of long setules. Two ejector hooks, of unequal size. Maxillar process with single seta.

LimB II. Exopodite narrow, elongated, with seta. Inner portion of limb with eight scraping spines, spines either of similar morphology, evenly decreasing in size basally, or spines 3 and 6 more robust, armed with thicker denticles. Distal armature of gnathobase with four elements. Filter plate II with seven setae, posteriormost considerably shorter than others.

LimB III. Exopodite rounded, with seven setae, seta 3 being longest, setae 6-7 of moderate length, setae 1-2 and 4-5 very short. Setae 1-5 plumose, setae 6-7 armed with short setules or naked. Distal endite with three setae, two distalmost ones slender, sharp, with denticles; basalmost seta shorter, geniculated, with thin setules. Basal endite with four stiff setae. Four soft setae increasing in size basally. Distal armature of gnathobase with four elements: elongated, cylindrical sensillum; thin, geniculated seta; and two short pointed spines. Filter plate III with seven setae.

LimB IV. Exopodite rounded, with six setae, setae 1-4 plumose, setae 5-6 with short setules or naked. Inner portion of limb IV with four setae and small sensillum. Distalmost seta robust, sharp, first flamingtorch seta (2) wide, armed with thick setules, two other 2-3 times thinner, armed with thin setiules. Three short soft setae increasing in size basally. Gnathobase with one long 2-segmented seta and a blunt process near it. Filter plate IV with five setae.

LimB V. Exopodite V separated into two lobes, with 4 plumose setae, seta 1 longest, evenly decreasing in width basally. Inner limb portion as elongated lobe. At inner face, two setae with wide bases, one 1.5-2 times longer than other. Filter comb V with three setae.

Limв VI. Large, of same size or larger than exopodite V, an oval lobe with setulated margin.

\section{Male}

Body lower than in female, similar to that of juveniles, with weakly convex dorsal margin. Postabdomen moderately long, narrowing distally, with obtuse preanal angle, gonopores located at of the end of the genital process protruding above the postabdominal claws. Clusters of setules in place of female marginal denticles, lateral fascicles of setules as in female. Postabdominal claw much shorter than in female, weakly curved, with short basal spine or without spine. Antennule shorter and wider than in female, with twelve terminal aesthetascs, male seta long. Limb I with U-shaped copulatory hook. IDL seta 1 absent, male seta large, of similar size with setae 2 and 3.

\section{Etymology}

The name is formed by adding the prefix flavo-, from the Latin adjective flavus, "yellow", to the preexisting name Alona, to express the fact that many of its species often are yellow-golden in color.

\section{Differential diagnosis}

Stands out from other Aloninae by the morphology of the lateral head pores. Also differs from all other Alona s.l. by a male postabdomen with gonopores at the end of a penis-like process (similar structures only in Leydigia Kurz, 1875 and Armatalona Sinev, 2004). Flavalona gen. nov. belongs to the Hexalonabranch of Alona s.l. and differs from Alona s. str. (see Van Damme \& Dumont 2008b), Ovalona (see Sinev 2015b) and genera of the Coronatella-branch (see Van Damme \& Dumont 2008a) by the presence of six trunk limbs and a filter plate V of three setae. Within Hexalona, Flavalona gen. nov. also differs 
from the affinis-group (see Alonso 1996; Sinev 2009) by its smaller size, shape of postabdomen, weakly developed lateral setules on the postabdomen, and weakly developed IDL seta 1; from the intermediagroup (see Alonso 1996) by the shape of the postabdomen, strong marginal denticles of the postabdomen, and by weakly developed lateral setules of the postabdomen; from the guttata-group (see Alonso 1996; Sinev \& Silva-Briano 2012) by a more elongated postabdomen with weakly developed preanal angle. Flavalona gen. nov. clearly differs from Matralona Van Damme \& Dumont, 2009, another genus related to the Hexalona-branch, in the shape and armament of the postabdomen, in a present IDL seta 1, and in an exopodite III with seven setae.

\section{Key to the known species of Flavalona gen. nov.}

1. Distal angle of postabdomen obtuse, with clearly defined tip F. weltneri (Keilhack, 1905) comb. nov.; West Palearctic

- Distal angle of postabdomen acute or with broadly rounded apex .............................2

2. Lateral head pores long, length over 0.5 IP. Distal angle of postabdomen acute .................

- Lateral head pores short, length about less than 0.5 IP. Distal angle of postabdomen rounded...7

3. Two major head pores ....................F. setigera (Brehm, 1931) comb. nov.; Australia and New Zealand, Neotropic

- Three major head pores

4. Lateral head pore pockets deep, rounded, depth ca 1.5-2 lateral pore length ..................5

- Lateral head pore pockets shallow, semicircular, depth ca $1 / 2-1 / 3$ pore length ..................6

5. Limb V strongly bilobed ......................... costata (Sars, 1962) s.1. comb. nov.; Holarctic

- Limb V only slightly bilobed F. margipluma (Sousa, Santos, Güntzel, Diniz, de Melo Junior \& Elmoor-Loureiro, 2015) comb. nov.; Neotropics

6. Valve sculpture composed of thin longitudinal striae or hexagons F. cheni (Sinev, 1999) comb. nov.; Indo-Malaya

- Valve sculpture composed of dense, broad longitudinal ridges F. natalensis (Sinev, 2008) comb. nov.; mountains of South Africa

7. Anterior margin of labrum with one or two denticles

F. bicolor (Frey, 1965) comb. nov.; East Nearctic

- Anterior margin of labrum without denticles .8

8. Length of adult female up to $0.7 \mathrm{~mm}$. Seta 6 of exopodite III about $2 / 3$ lengths of seta 3 ...F. hudeci (Sinev, 1999) comb. nov.; Neotropics (syn. Alona rusticoides Hudec, 1998)

- Length of adult female not exceeding $0.52 \mathrm{~mm}$. Seta 6 of exopodite III almost as long as seta $3 \ldots 9$

9. Lateral head pores dot-like with rounded pockets, widths of pockets over two lengths of pore ...... F. sphagnophila (Van Damme \& Eggermont, 2011) comb. nov.; Mountains of East Africa

- Lateral head pores transverse with semicircular pockets 10

10. Central major head pore located closer to posterior one. Exopodite V strongly bilobed. Epipodites IV-V with finger-like processes longer than epipodite itself

F. iheringula (Kotov \& Sinev, 2004) comb. nov.; Neotropics

- Central major head pore located halfway between anterior and posterior pores. Exopodite V not divided into two lobes. Epipodites IV-V without processes

F. rustica (Scott, 1901) s.l. comb. nov.; Holarctic 


\section{Costata-clade}

Characteristics of the costata-clade clade include: (1) valves with pronounced linear sculpture; (2) shortened anterior group of setae on valves, with longest setules in the middle of the group; (3) long lateral head pores with large pockets, length of pore over 0.5 IP. (4) postabdomen with acute or right distal angle; (5) lateral fascicles of setules on postabdomen with distalmost setae the longest; (6) male postabdomen with short genital process, its length about $1 / 3$ or less of length of claw.

The clade is rather uniform, with no marked differences in outer morphology. Flavalona natalensis comb. nov. differs by the sculpture of its valves, and $F$. weltneri comb. nov. by the shape of its postabdomen. Armament of postabdomen and morphology of head appendages similar within clade. Differences in thoracic limb morphology minimal, the only variable feature being the shape of exopodite $\mathrm{V}$, which can be bilobed or oval. Species differ mostly by the morphology of the major and lateral head pores. Male morphology known only in F. costata comb. nov. and F. setigera comb. nov., but no significant difference between them.

Flavalona costata (Sars, 1862) comb. nov.

Figs $1-2$

Alona costata Sars, 1862: 286.

Alona lineata Schoedler, 1862: taf. I, fig. 23.

Phryxira rectirostris Müller, 1867: 184-185, tab. IV, fig. 15.

Lynceus costatus Norman \& Brady, 1867: 28, pl. XVIII, fig. 2, pl. XXI, fig. 7.

Lynceus costata Lilljeborg, 1901: 465-468, tab. LXVIII, fig. 9-15.

Alona costata - Hellich 1877: 90, figs 47-48. — Behning 1941: 299-301, fig. 123. — Šrámek-Hušek et al. 1962: 336-338, fig. 124. - Herbst 1962: 86, fig. 61. — Frey 1965): 159-162, figs 1-6. — Flössner \& Frey 1970: 327, figs 4, 6-7. — Smirnov 1971: 371-373, figs 345-340. — Flössner 1972: 299-301, figs 140-141. — Negrea 1983: 291-292, fig. 118. — Margaritora 1985: 313-315, fig. 124. — Sars 1993: 135, pl. 98. - Alonso 1996: 322-323, fig. 143. - Flössner 2000: 315-322, fig. 117. — Sinev 1999a: 132-138, figs 1-5. — Sinev 2002: 394, figs 3в,м, 4в, 5в, 3. — Hudeč 2010: 319-322, fig. 77. — Sinev et al. 2015: fig. 1A-C.

Alona lineata - Müller 1867: 178, table IV, figs 2-3.

non Alona costata - Idris 1983: 106-108, fig. 50.

\section{Differential diagnosis}

Flavalona costata comb. nov. differs from F. setigera comb. nov. by having three main head pores, and from $F$. natalensis comb. nov. and $F$. cheni comb. nov. by the deep pockets of the lateral head pores; in these species the depth of the pockets is less than half the depth of the pore. It also differs from F. natalensis comb. nov. by the costata-like sculpture of its valves. Flavalona costata comb. nov. is similar in morphology to F. margipluma comb. nov. too but differs by the basal spine of its postabdomen exceeding the width of the claw base and by having a bilobed exopodite $\mathrm{V}$.

As Flavalona costata comb. nov. is the type species of Flavalona gen. nov., a detailed description follows.

\section{Type material}

Material in Sars' collection (Zoological Museum of Oslo University, F12410) labeled "Norway"; no exact locality or dates given. 


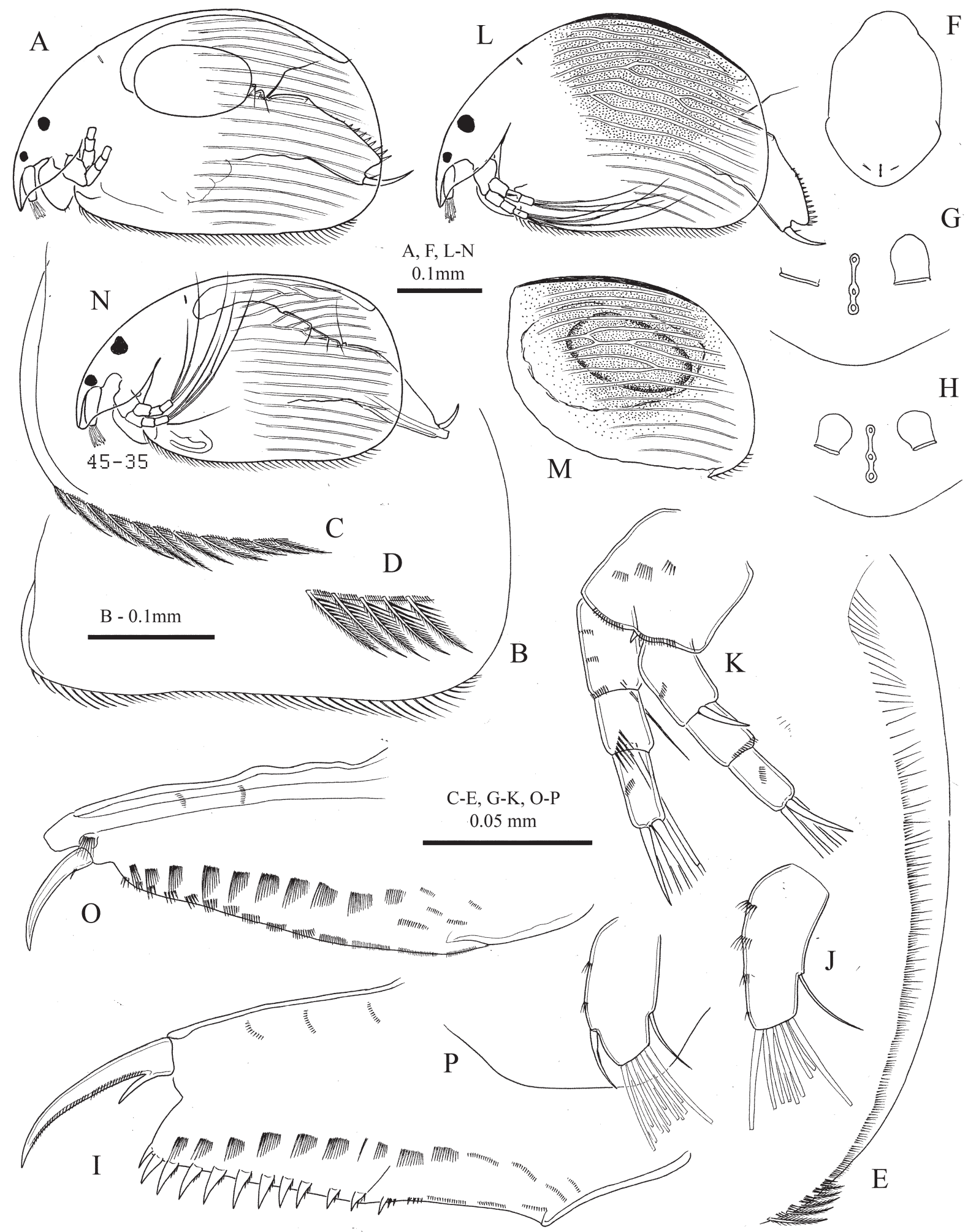

Fig. 1. Flavalona costata (Sars, 1862) comb. nov., Randsfjorden Lake, Norway. A-K. Parthenogenetic +. A. Lateral view. B. Ventral margin of valves. C. Anterior setae of valves. D. Posterior setae of valves. E. Posteroventral corner and posterior margin of valves. F. Head shield. G-H. Head pores. I. Postabdomen. J. Antennule. K. Antenna. L. Ephippial + . M. Ephippium. N-P. ふ. N. Lateral view. O. Postabdomen. P. Antennule and outline of rostrum. 


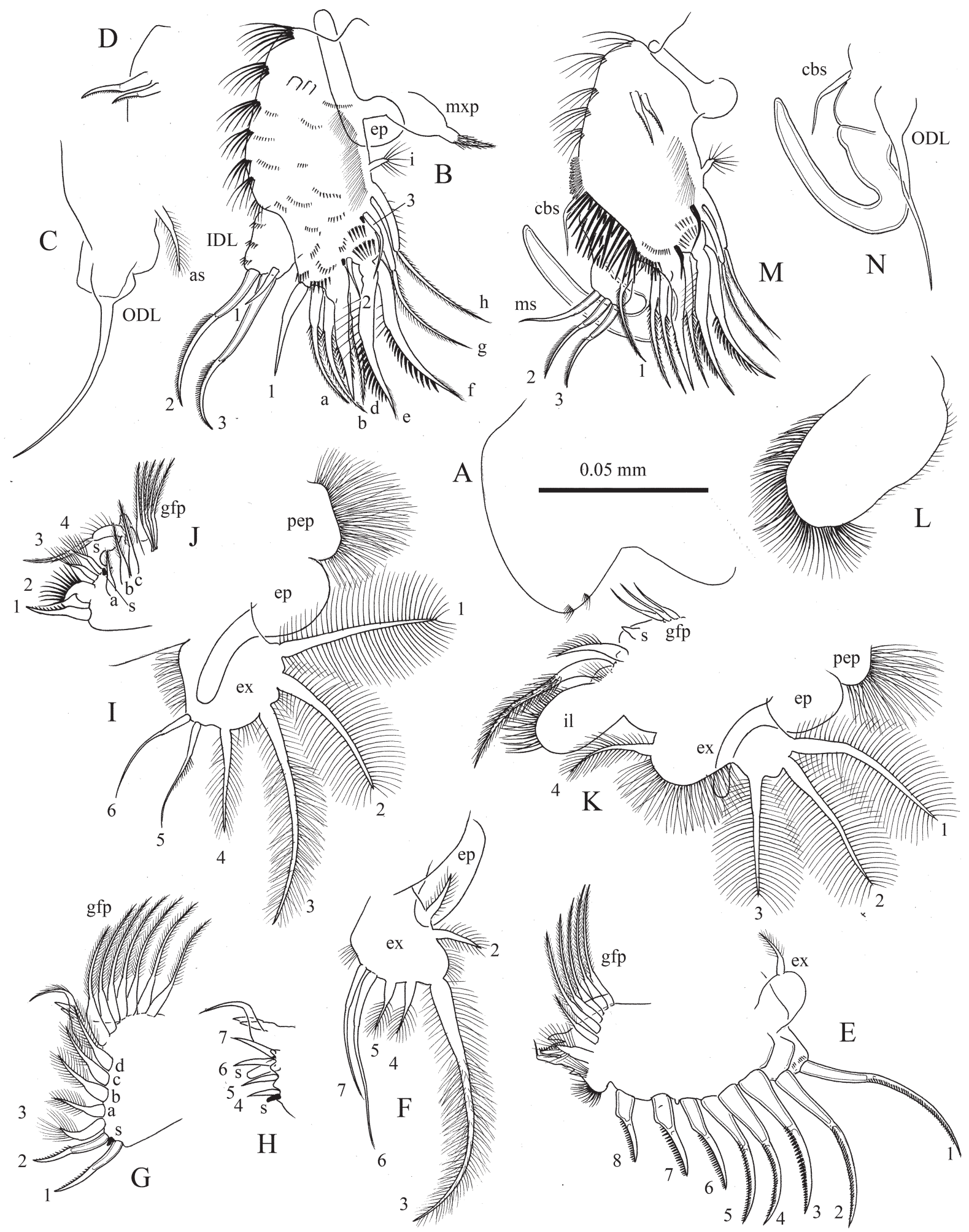

Fig. 2. Flavalona costata (Sars, 1862) comb. nov., Randsfjorden Lake, Norway. A-L. Labrum and thoracic limbs of parthenogenetic 9 . A. Labrum. B. Limb I. C. ODL of limb I. D. Ejector hooks of limb I. E. Limb II. F. Exopodite of limb III. G-H. Inner portion of limb III. I. Exopodite of limb IV. J. Inner

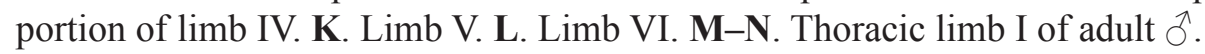




\section{Material studied earlier}

See Sinev (1999a) for list of material from Norway, Poland, Germany, Russia and Mongolia.

\section{Material studied here}

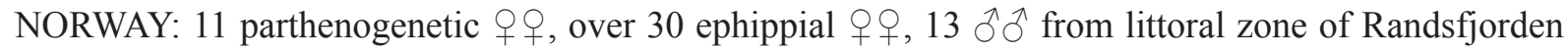
Lake, $60^{\circ} 14.37^{\prime} \mathrm{N}, 10^{\circ} 23.94^{\prime}$ E, 9 Oct. 2015, coll. A.Y. Sinev \& T. Jensen.

CHINA: over 30 parthenogenetic $q \propto$ from littoral zone of Erhai lake, Yunnan Province, $25^{\circ} 49.887^{\prime} \mathrm{N}$, $100^{\circ} 13.166^{\prime}$ E, 19 Jan. 2015, coll. A.Y. Sinev \& Y. Gu; 3 parthenogenetic $q 9$ and exuviae from artificial lake in Botanical Garden of Changsha City, Hunan Province, $28^{\circ} 06.253^{\prime} \mathrm{N}, 113^{\circ} 01.783^{\prime} \mathrm{E}, 10$ Apr. 2014, coll. A.Y. Sinev \& Y. Gu; 8 parthenogenetic 9 우 from artificial lake in Botanical garden of Guangzhou City, Guangdong Province, $23^{\circ} 11.225^{\prime}$ N, $113^{\circ} 21.834^{\prime}$ E, 5 Apr. 2014, coll. A.Y. Sinev \& Y. Gu; over 30 parthenogenetic $ᄋ$ 우 from Shuisheng reservoir, Hainan island, 18 $53.097^{\prime} \mathrm{N}, 110^{\circ} 23.514^{\prime} \mathrm{E}, 24 \mathrm{Apr}$. 2014, coll. A.Y. Sinev \& Y. Gu.

\section{Type locality}

Lake Ostensjovand, Oslo, Norway.

\section{Description}

\section{Parthenogenetic female}

Length of adult up to $0.5 \mathrm{~mm}$. In lateral view body oval or slightly ovoid (Fig. 1A), maximum height at middle or somewhat behind it, height-length ratio ca $0.58-0.65$. Dorsal margin uniformly curved. Postero-dorsal and postero-ventral angles broadly rounded. Posterior margin uniformly curved. Ventral margin almost straight, with about 50-60 setae (Fig. 1B), about 10 first setae of moderate length, next 15 setae short, other setae of moderate length. Setae of the anterior group (Fig. 1C) not longer than those of the posterior group (Fig. 1D), longest setae of anterior group located at the middle of the group. Groups of small setules located between the bases of all ventral setae. Posteroventral angle (Fig. 1E) with only $10-15$ short setules protruding beyond margin of valves. A row of about 150 setules along posterior margin on inner side of carapace. In ventral third of the row these setules uniform, in middle third, row formed by long setules and groups of shorter setules between them, in dorsal third by long setules only. Carapace covered by moderately thick, sparsely spaced longitudinal lines, without intervening striae.

Head relatively small, triangular-round in lateral view, rostrum short, pointing downward. Eye larger than ocellus. Distance from tip of rostrum to ocellus greater than that between ocellus and eye.

Head shield with maximum width behind mandibular articulation, without any sculpture (Fig. 1F). Rostrum short, broadly rounded. Posterior margin of head shield broadly rounded. Three major head pores (Fig. 1G-H), middle pore slightly smaller than others, located closer to posterior pore. Connection between anterior and middle pores narrow, connection between middle and anterior pores varies from narrow to rather wide in some populations (see Alonso 1996; Sinev et al. 2015). PP a. 0.5-0.8 IP. Transverse lateral head pores ca $0.5-0.8$ IP lengths, located about 0.5 IP distance from midline, at a level between anterior and middle main head pores. Lateral pore pockets large, rounded, with depth ca 1.5-2 pore lengths.

Labrum moderate size (Fig. 2A). Distal labral plate without setulation. Labral keel of moderate width, with a blunt or rounded apex. Anterior margin of keel convex, posterior margin with two clusters of setules.

Thorax and abdomen subequal in length, dorsal surface of abdominal segments not saddle-shaped. Second abdominal segment with two transverse rows of setules. 
Postabdomen (Fig. 1I) wide, narrowing distally, with well defined, acute angle between distal and dorsal margins, length about 2.2-2.5 times height. Ventral margin straight. Inflated basis of claws bordered from distal margin by clear incision. Distal margin weakly convex to straight. Dorsal margin with distal part about 3 times longer than preanal one, with postanal portion about 1.5 times longer than anal one. Postanal portion of distal margin straight, anal portion weakly concave. Preanal and postanal angles weakly defined. Preanal margin almost straight. Postabdomen with 8-9-10 well-developed composite marginal denticles, each with several spinules on anterior margin, and with two groups of marginal spinules and 2-3 groups of short setules on anal margin. Length of denticles decrease basally, length of longest denticles exceed the width of postabdominal claw base. Ten-twelve lateral fascicles of thin setules; in postanal fascicles distalmost seta being longest, 1.5 times shorter than marginal denticles. Postabdominal claw of moderate length, somewhat longer than preanal portion of postabdomen. Basal spine ca 0.2 of length of claw.

Antennule (Fig. 1J) moderate length, almost reaching the tip of rostrum, with four transverse rows ofshort setules at anterior face. Antennular sensory seta slender, 1.5 times shorter than antennule, arising at $2 / 3$ distance from base. Nine aesthetascs, two of them longer than others, of about $2 / 3$ length of antennule, others of similar length. .

Antenna (Fig. 1K) moderate length. Antennal formula, setae $0-0-3 / 1-1-3$, spines $1-0-1 / 0-0-1$. Basal segment robust, branches elongated, slender, all segments cylindrical, with short setules around distal margin. Seta arising from basal segment of endopodite short and thin, not reaching tip of distal segment. Seta arising from middle segment of endopodite of similar size with apical setae. Spine on basal segment of exopodite shorter then middle segment. Apical spines slightly longer than respective apical segments.

Thoracic limbs six pairs.

LimB I (Fig. 2B-D). Epipodite oval, with finger-like process 2 times longer than epipodite itself. Accessory seta about $1 / 3$ length of ODL seta. IDL with three setae and several clusters of small setules on ventral face, IDL seta 1 small, thin, setae 2 and 3 subequal in length to ODL seta, both with thin setules in distal part. Endite 3 with inner seta (1) shorter than outer setae $(a-c)$. Endite 2 with three outer setae (d-f) and short inner seta (2) and sensillum near its base, setae e-f short, about half length of limb itself, seta f slightly longer than seta e. Endite 1 with inner seta (3) longer than inner seta of endite 2 and sensillum near its base, two 2-segmented setae $(\mathrm{g}-\mathrm{h})$, both setulated in distal part, and a flat seta (i) of characteristic shape, with reduced distal portion, armed with long setules. Seven rows of thin long setules on ventral surface of limb. Two ejector hooks, one of them 1.5 times longer than the other. Maxillar process elongated, with single seta.

LimB II (Fig. 2E). Exopodite oval, with seta almost as as long as exopodite. Eight scraping spines, scrapers 1-5 long, scrapers 6-8 much shorter, armed with small setules. Scrapers 3 and 6 of similar length with neighbors, but slightly thicker and armed with slightly more thick setules. Distal armature of gnathobase with four elements. Filter plate with seven setae, the posteriormost seta considerably shorter and thicker than other, armed with very long setules, next seta of same morphology with others, but two times shorter.

LimB III (Fig. 2F-H). Epipodite oval, without finger-like process. Exopodite trapezium-shaped, with seven setae. Seta 3 being longest, setae 6 and 7 of $2 / 3$ and $1 / 2$ length of seta 3 , respectively, other setae short. Setae 6 and 7 naked, all other plumose, setules on seta 3 considerably longer than on short setae. Distal endite with three setae, two distalmost members slender, sharp, of similar length, with distal parts unilaterally armed small sharp denticles; basalmost seta thicker, bilaterally armed with long setules. Basal endite with four plumose outer setae (a-d), increasing in size in basal direction. Four inner setae (4-7) increasing in size basally, a small sensillum near the base of distalmost seta (4). Distal armature 
of gnathobase with four elements. The first one elongated, cylindrical sensillum, second thin, bent seta, others two - blunt spines with fused bases. Filter plate III with seven setae.

LimB IV (Fig. 2I-J). Pre-epipodite setulated; epipodite with a finger-like process longer than epipodite itself. Exopodite subquadrangular, with six setae. Seta 3 the longest, seta 1-2 slightly shorter, setae 4-6 ca $2 / 3$ length of seta 3 , setae 5-6 slightly longer than seta 4 . Setae 1-4 flat, plumose, setae 5-6 slender, seta 5 with short setules at the middle, seta 6 naked. Inner-distal portion of limb IV with four setae and small rounded sensillum. Seta 1 slender, sharp, armed with short spinules. Distal flaming-torch seta (2) of typical for Aloninae shape, broad, with curved distal portion, armed with about 10 long thick setules. Two other flaming-torch setae (3-4) thin and straight, with straight distal portion, armed with thin, hair-like setules, a small sensillum located near their bases. Three inner setae (a-c) long, increasing in size basally. Gnathobase with a short 2-segmented seta, only little longer than seta 1, and a hillock with sensilla distally. Filter plate with five setae.

LimB V (Fig. 2K). Pre-epipodite setulated, epipodite with finger-like process longer than epipodite itself. Exopodite bilobed, with 4 plumose setae. Seta 1 being longest, setae $2-3$ slightly shorter than seta 1 , seta 4 two times shorter than seta 1 . Inner limb portion an elongated oval lobe, with setulated inner margin. At inner face, two setae, one three times longer than other, and a triangular sensillum. Filter plate with three setae.

Limi VI (Fig. 2L). An elongated lobe, its length about twice maximum width, its margin densely setulated in distal part.

\section{Ephippial female}

Outline similar to that of parthenogenetic female (Fig. 1L), dorsal margin more highly arched in most specimens. Ephippium of living specimens blackish, in preserved specimens yellow-brown. Ephippium (Fig. 1M) sculptured by anastomosing longitudinal lines, thicker than in ventral portion of valves.

\section{Adult male}

Length $0.36-0.42 \mathrm{~mm}$. Body (Fig. 1N) low oval, dorsal margin weakly convex. Maximum height at the middle of the body, height/length ratio ca 0.55 . Ocellus larger that in female. Rostrum short, slightly truncated (Fig. 1P).

Postabdomen (Fig. 1O) moderately long, narrowing distally in postanal part. Ventral margin straight or wavy. Basis of claws bordered from distal margin by clear incision. Genital process short, about $1 / 4-1 / 3$ length of postabdominal claw. Distal margin very short, distal angle obtuse. Dorsal margin concave in anal portion, straight in postanal portion. Preanal and postanal angles not defined. Clusters of short setules in place of marginal denticles, distalmost cluster consisting of 3-5 thick short setules. Lateral fascicles as in female. A cluster of short setules above the base of postabdominal claw. Postabdominal claw as long as preanal portion of postabdomen, weakly curved. Basal spine short and thin, visible only under oil immersion.

Antennule (Fig. 1P) shorter and broader than in female, with 12 terminal aesthetascs, longest about $3 / 4$ length of antennule, shortest ca $1 / 2$ length of antennule. Male seta arising at $1 / 4$ length from tip, ca $1 / 3$ length of antennule.

Thoracic limb I (Fig. 2M-N) with U-shaped copulatory hook, half as long as limb itself. IDL with three setae, IDL seta 1 absent. IDL setae 2 and 3 much thinner and two times shorter than in female, of similar length. Male seta curved, slightly shorter than seta 2 . Copulatory brush seta ca $2 / 3$ length of IDL seta 2 . Ventral face of the limb under the copulatory brush with row of 20 long stiff stiff setules. Inner seta (1) of endite 3 longer and thinner than in female, with long setules distally. 
For description of juvenile males and females, see Sinev (1999a).

Our data agree with those of previous descriptions of the species, but add several features. Thin setules between ventral setae of the valves were overlooked by Sinev (1999), so Sousa et al. (2015) used this feature as diagnostic for F. margipluma comb. nov. Most authors also overlooked the basal spine of the male postabdomen.

\section{Distribution}

Presumed Holarctic (Flössner \& Frey 1970; Smirnov 1971). Flavalona costata comb. nov. is found in the whole of Europe, European and Asian Russia, Kazakhstan, Mongolia, China, Korea and Japan but its southern limit is unclear (Smirnov 1971; Sinev 1999a). The southernmost certified record is from Hainan Island (Sinev et al. 2015). It has been cited from mainland South-East Asia (see Korovchinsky 2013) and India (see Chatterjee et al. 2013), but these records were not accompanied by descriptions, and the related F. cheni comb. nov. is present in these regions. Flössner \& Frey (1970) found no significant differences between North American and European F. costata comb. nov., but the appendages were not studied, so possibly Nearctic populations constitute a separate species.

Flavalona cheni (Sinev, 1999) comb. nov.

Fig. 3A

Alona cheni Sinev, 1999a: 142-146, figs 8-10.

Alona cheni - Maiphae et al. 2008: 6, fig. 3.

Alona costata - Idris 1983: 106-108, fig. 50.

Alona setigera - Chen \& Peng 1993: 19, figs 1-5.

\section{Diagnosis}

Female

Length of adult up to $0.47 \mathrm{~mm}$. Body regular oval, maximum height at the middle of body, height/ length ratio ca 0.6. Valves from previous molts not retained. Posteroventral angle without setules protruding beyond valve margins. Ventral margin with ca 45 setae. Valves covered by thin, sparsely spaced longitudinal lines.

Eye larger than ocellus. Rostrum short, broadly rounded. Posterior margin of head shield broadly rounded. Three major head pores (Fig. 3A), middle pore slightly smaller than others, located near posterior pore. Connection between middle and posterior pore wide, connection between middle and anterior pore narrow. PP ca 0.7-0.9 IP. Lateral head pores of ca 0.9-1.2 IP length, lateral pore pockets semicircular, with depth ca 0.5 of pore length. Labral keel without denticles.

Postabdomen truncated, length 2.2-2.4 heights. Distal margin straight, distal angle prominent, acute with rounded tip. Dorsal margin weakly convex in preanal part, concave in anal part, straight in postanal part. Distal part of dorsal margin 3 times longer than preanal one, with preanal portion 1.3-1.5 times longer than anal one. Preanal and postanal angles weakly defined. Postanal margin of postabdomen provided with 10-14 marginal denticles. Anal margin with 4-5 clusters of marginal setules. 10-12 lateral fascicles of setules, distal setules in fascicle being longest. Postabdominal claw of moderate length, 1.5 times longer than preanal portion of postabdomen. Basal spine ca 0.15 of length of claw.

Antennule with longest aesthetasc of ca $2 / 3$ the ength of antennule. Scrapers of limb II of similar morphology. Exopodite III with seta 6 of ca $2 / 3$ the length of seta 3 . Exopodite IV with seta 3 being 
longest, setae 1-2 slightly shorter, setae 4-6 ca 0.4 length of seta 3. Epipodites IV without process. Exopodite V strongly bilobed. Epipodite V with processes as long as epipodite itself.

\section{Male}

Unknown.

\section{Differential diagnosis}

Flavalona cheni comb. nov. differs from $F$. setigera comb. nov. in having three major head pores; from F. costata comb. nov. and F. margipluma comb. nov. by the morphology of lateral head pores, with semicircular pore pockets about half the depth of pore length; from $F$. natalensis comb. nov. in the typical costata-like sculpture of the valves; from $F$. weltneri comb. nov. in the shape of its postabdomen.

\section{Type material}

\section{Holotype}

Parthenogenetic $\$$, Zoological Museum of Moscow State University, ML-05.

\section{Paratypes}

Two dissected parthenogenetic $ㅇ ㅜ$ on slides, Zoological Museum of Moscow State University, Ml-06, ML-07.

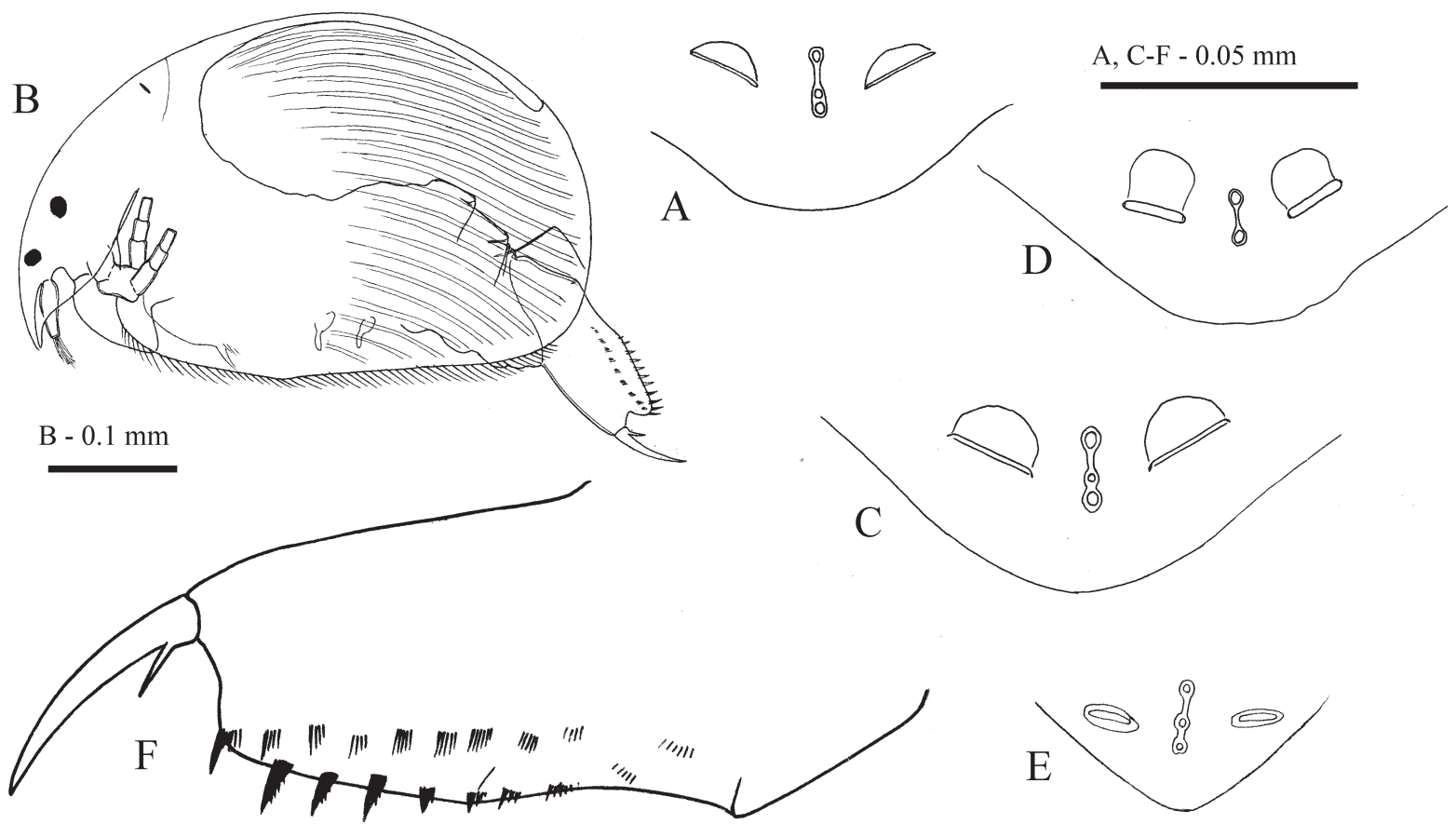

Fig.3. A. Flavalona cheni (Sinev, 1999) comb. nov., head pores of parthenogenetic + . B-C. Flavalona natalensis (Sinev, 2008) comb. nov., parthenogenetic 9. B. Lateral view. C. Head pores. D. Flavalona setigera (Brehm, 1931) comb. nov., head pores of parthenogenetic 9 . E-F. Flavalona weltneri (Keilhack, 1905) comb. nov., parthenogenetic $q$. E. Head pores. F. Postabdomen. Figures A and D from Sinev (1999a), B-C from Sinev (2008), E redrawn from Flössner (2000) and F redrawn from Van Damme et al. (2010). 


\section{Material studied earlier}

See Sinev (1999a) for list of material from India and Maiphae et al. (2008) for a list of material from Thailand.

\section{Type locality}

INDIA: Aiwa reservoir, Ahmedabad.

\section{Distribution}

India, South-East Asia and China (Sinev 1999a; Maiphae et al. 2008; Idris 1983), northernmost record in China from Wuhan province (Chen \& Peng 1993).

\section{Flavalona margipluma}

(Sousa, Santos, Güntzel, Diniz, de Melo Junior \& Elmoor-Loureiro, 2015) comb. nov.

Alona margipluma Sousa, Santos, Güntzel, Diniz, de Melo Junior \& Elmoor-Loureiro, 2015: 445-455, figs $1-4$.

Alona iheringula - Silva, Abreu, Orlando, Wisniewski \& Santos-Wisniewski 2014: 2-5, fig. 1.

Diagnosis (according to Sousa et al. 2015)

\section{Female}

Length of adult $0.32-0.43 \mathrm{~mm}$. Body regular oval, maximum height at mid-body, height/length ratio about 0.65 . Valves from previous molts not retained. Posteroventral angle without setules protruding beyond valve margins. Ventral margin with $45-50$ setae. Valves covered by thin, sparsely spaced longitudinal lines.

Eye larger than ocellus. Rostrum short, broadly rounded. Posterior margin of head shield broadly rounded. Three major head pores, middle pore slightly smaller than others, located near posterior pore. Connection between middle and posterior pore wide, connection between middle and anterior pore narrow. PP ca $0.7-0.95$ IP. Lateral head pores of ca $0.7-0.85$ IP length, lateral pore pockets rounded, with depth about 1.5 of pore length. Labral keel without denticles.

Postabdomen truncated, length 2.4-2.6 heights. Distal margin straight, distal angle prominent, acute with rounded tip. Dorsal margin weakly convex in preanal part, concave in anal part, straight in postanal part. Distal part of dorsal margin 3 times longer than preanal one, with preanal portion 1.3-1.5 times longer than anal one. Preanal and postanal angles weakly defined. Postanal margin of postabdomen provided with 11-13 marginal denticles. Anal margin with 4-5 clusters of marginal setules. About 10 lateral fascicles of setules, distal setules in fascicle being longest. Postabdominal claw of moderate length, longer than preanal portion of postabdomen. Basal spine small, its length less than width of postabdominal claw base.

Antennule with longest aesthetasc of about $2 / 3$ length of antennule. Scrapers of limb II of similar morphology. Exopodite III with seta 6 of ca $2 / 3$ length of seta 3 . Exopodite IV with seta 3 being longest, setae 1-2 slightly shorter, setae 4-6 ca 0.5 length of seta 3 . Epipodite IV and V with processes as long as the epipodite itself. Exopodite V not bilobed.

Male

Unknown. 


\section{Differential diagnosis}

Flavalona margipluma comb. nov. differs from F. setigera comb. nov. by three main head pores, from $F$. natalensis comb. nov. and $F$. cheni comb. nov. by deep pockets of lateral head pores (in these species the depth of the pockets is less than half the depth of the pore). It also differs from F. natalensis comb. nov. by its costata-like valve sculpture. Flavalona margipluma comb. nov. is similar in morphology to $F$. costata comb. nov., but differs in exopodite $\mathrm{V}$ not separated into two lobes and in basal spine of postabdomen shorter than the width of claw base. Unique to the species is the bottle-shaped main sensillum of limb IV. Sousa et al. (2015) suggested that the presence of thin setules between the bases of setae on the ventral valve margin is unique to F. margipluma comb. nov., but such setules are present in all Flavalona gen. nov., yet were overlooked in previous studies.

\section{Type material}

\section{Holotype}

Adult parthenogenetic $q$, the Museum of Zoology of the University of São Paulo, MZUSP 33196.

\section{Paratypes}

See Sousa et al. (2015) for the list of paratypes.

\section{Type locality}

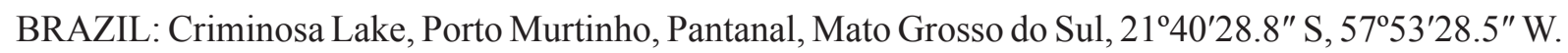

\section{Distribution}

So far known from Mato Grosso do Sul state, Pernambuco state and Distrito Federal of Brazil (Sousa et al. 2015). In littoral zone of lakes among macrophytes.

Flavalona natalensis (Sinev, 2008) comb. nov.

Fig. 3B-C

Alona natalensis Sinev, 2008: 24-32, fig. 1-4.

\section{Diagnosis}

\section{Female}

Length of adult $0.46-0.54 \mathrm{~mm}$. Body (Fig. 3B) regular oval, maximum height at the middle of body, height/length ratio about 0.6 . Valves from previous molts not retained. Posteroventral angle without setules protruding beyond valve margins. Ventral margin with ca 50 setae. Valves covered by dense, broad longitudinal lines.

Eye larger than ocellus. Rostrum short, broadly rounded. Posterior margin of head shield broadly rounded. Three major head pores (Fig. 3C), middle pore slightly smaller than others, located near the posterior pore. Connection between middle and posterior pore wide, connection between middle and anterior pore narrow. PP ca 1.1-1.5 IP. Lateral head pores of ca 1.0-1.2 IP length, lateral pore pockets shallow, with depth about $1 / 3$ of pore length. Labral keel without denticles.

Postabdomen truncated, length 2.2-2.4 heights. Distal margin straight, distal angle prominent, acute, with rounded tip. Dorsal margin weakly convex in preanal part, concave in anal part, straight in postanal part. Distal part of dorsal margin 3 times longer than preanal one, with preanal portion 1.3-1.5 times longer than anal one. Preanal and postanal angles weakly defined. Postanal margin of postabdomen provided with 8-10 marginal denticles. Anal margin with 4-5 clusters of marginal setules. 10-12 lateral 
fascicles of setules, distal setules in fascicle being longest. Postabdominal claw of moderate length, 1.5 times longer than preanal portion of postabdomen. Basal spine about 0.2 of length of claw.

Antennule with longest aesthetasc of about $2 / 3$ length of antennule. Scrapers of limb II of similar morphology. Exopodite III with seta 6 of about $2 / 3$ length of seta 3 . Exopodite IV with seta 3 being longest, setae 1-2 slightly shorter, setae 4 about half length of seta 3 , setae 5-6 about $2 / 3$ length of seta 3 . Epipodites IV-V with processes about 1.5 of epipodite length. Exopodite V weakly bilobed.

Male

Unknown.

\section{Differential diagnosis}

Flavalona natalensis comb. nov. has a characteristic sculpture of the valves, composed of thick, closely spaced longitudinal lines.

\section{Type material}

\section{Holotype}

Parthenogenetic $q$, Zoological Museum of Moscow State University, Ml-44.

\section{Paratypes}

Seven parthenogenetic $q \rightarrow$, Zoological Museum of Moscow State University, Ml-45.

\section{Material studied earlier}

See Sinev (2008) for a list of material from the Republic of South Africa and Lesotho.

\section{Type locality}

SOUTH AFRICA: Lakes Cave Tarn 3, Cobham, KwaZulu-Natal Province, 29³9'50" S, 29¹8'47" E, altitude 2190 m.a.s.1.

\section{Distribution}

Inhabits small, possibly temporary, water bodies (pools and tarns) in the East Escarpment portion of the Drakensberg Mountains in KwaZulu-Natal and Lesotho (Sinev 2008). At the time of sampling, pH was 6 to 7.6 , and temperature 16.4 to $22^{\circ} \mathrm{C}$. It belongs to the complex of endemic species of the Drakensberg mountains, which includes five other benthic cladocerans viz. Pleuroxus carolinae (Methuen, 1910), Dumontiellus africanus Smirnov, 2007, Alona meridionalis Sinev, 2006, A. martensi Sinev, 2009 (Chydoridae) and Ilyocryptus martensi Kotov \& Štifter, 2005 (Ilyocryptidae) (see Van Damme et al. 2013). All are restricted to the eastern escarpment of the Drakensberg, which lies within an area with an effective temperature index below $14^{\circ} \mathrm{C}$ (Stuckenberg 1969). The index of temperature expresses the relative duration of the warm period of year.

\section{Flavalona setigera (Brehm, 1931) comb. nov.}

Fig. 3D

Alona guttata var. setigera Brehm, 1931: 499-501, figs 5-7.

Biapertura setigera Smirnov \& Timms, 1983: 58-59, figs 67-68.

Biapertura rusticoides Smirnov \& Timms, 1983: 64, fig. 75.

Alona setigera Sinev, 1999a: 138-142, figs 5-8.

non Alona setigera - Chen \& Peng 1993: 19, figs 1-5. 


\section{Diagnosis}

Female

Length $0.39-0.49 \mathrm{~mm}$. Body regular oval, maximum height at mid-body, height/length ratio ca 0.6. Valves from previous molts not retained. Posteroventral angle without setules protruding beyong valve margins. Ventral margin with about 40 setae. Valves covered by thin, sparsely spaced longitudinal lines.

Eye larger than ocellus. Rostrum short, broadly rounded. Posterior margin of head shield broadly rounded. Two major head pores (Fig. 3D) with narrow connection between them. PP ca 1.1-1.3 IP. Lateral head pores of ca $0.9-1.0$ IP length, lateral pore pockets semicircular, with depth about 1 pore length. Labral keel without denticles.

Postabdomen truncated, length about 2.5 heights. Distal margin straight, distal angle prominent, acute with rounded tip. Dorsal margin weakly convex in preanal part, concave in anal part, straight in postanal part. Distal part of dorsal margin 3 times longer than preanal one, with anal and postanal portion of similar length. Preanal and postanal angles weakly defined. Postanal margin of postabdomen provided with 10-14 marginal denticles. Anal margin with 4-5 clusters of marginal setules. 10-12 lateral fascicles of setules, distal setules in fascicle being longest. Postabdominal claw of moderate length, 1.5 times longer than preanal portion of postabdomen. Basal spine about 0.15 of length of claw.

Antennule with longest aesthetasc about $2 / 3$ of length of antennule. Scrapers of limb II of similar morphology. Exopodite III with seta 6 of ca $2 / 3$ length of seta 3 . Exopodite IV with seta 3 being longest, setae 1-2 slightly shorter, setae 4-6 ca 0.4 length of seta 3 . Epipodite IV-V without process. Exopodite $\mathrm{V}$ bilobed. Epipodite V with processes as long as epipodite itself.

\section{Male}

Length of adult $0.38-0.4 \mathrm{~mm}$. Body low oval, dorsal margin weakly convex. Maximum height at the middle of the body, height/length ratio $0.55-0.58$. Ocellus larger that in female.

Postabdomen moderately long, narrowing distally in postanal part. Ventral margin almost straight. Genital process about $1 / 3$ length of postabdominal claw. Distal margin short, distal angle obtuse. Dorsal margin concave in anal portion, straight in postanal portion. Preanal and postanal angles not defined. Clusters of short setules in place of marginal denticles, distalmost cluster consisting of 3-5 thick short setules. Postabdominal claw as long as preanal portion of postabdomen, weakly curved. Basal spine not found.

Antennule with male seta arising at $1 / 4$ length from tip, about $1 / 3$ length of antennule.

Thoracic limb I with IDL setae 2 and 3 much thinner and two times shorter than in female, of similar length. Male seta curved, slightly shorter than seta 2 . Ventral face of the limb under the copulatory brush with row of 20 long stiff setules. Inner seta (1) of endite 3 longer and thinner than in female, with long setules distally.

\section{Differential diagnosis}

Flavalona setigera comb. nov. differs from all species of Flavalona gen. nov. by the presence of only two major head pores.

\section{Type material}

Non-existent. 


\section{Material studied earlier}

See Sinev (1999) for a list of material from Australia.

\section{Type locality}

New Zealand.

\section{Distribution}

Australia, New Zealand (Sinev 1999a) and Brazil (Santos-Wisniewsky et al. 2001). Currently the only species with a transpacific range. However, since the limbs of American populations were not studied, these may turn out to represent a separate species.

Flavalona weltneri (Keilhack, 1905) comb. nov. Fig. 3E-F

Alona weltneri Keilhack, 1905: 158-159, figs 13-14.

Alona weltneri - Keilhack 1908: 464, fig. 20. — Flössner 1972: 306-308, fig. 144. — Smirnov 1971: 365-366, figs 425-426. — Flössner 2000: 322-323, fig. 119. — Van Damme, Elais-Gutierrez \& Dumont 2011: 51-53, figs 3-4.

Diagnosis (according to Flössner 2000 and Van Damme et al. 2011).

\section{Female}

Length of adult up to $0.45-0.53 \mathrm{~mm}$. Body regular oval, maximum height after the middle of body, height/length ratio about 0.57 (the holotype, studied by Van Damme et al. (2011) was deformed, and its reconstruction (Van Damme et al. 2011: fig. 3A) is uncertain). Valves from previous molts not retained. Posteroventral angle without setules protruding beyond valve margins. Ventral margin with ca 45 setae. Valves covered by thin, sparsely spaced longitudinal lines.

Eye larger than ocellus. Rostrum short, broadly rounded. Posterior margin of head shield broadly rounded. Three major head pores (Fig. 3E), middle pore slightly smaller than others, located near posterior pore. Connections between pores narrow. PP ca 0.4 IP. Lateral head pores of ca 0.5 IP length, lateral pore pockets not studied in details, but probably shallow. Labral keel without denticles.

Postabdomen (Fig. 4F) truncated, length 2.3 heights. Unlike all other species, no incursion between postabdominal claw base and distal margin. Distal margin straight, distal angle obtuse, not prominent, with rounded tip. Dorsal margin straight in preanal part, concave in anal part, straight in postanal part. Distal part of dorsal margin 3 times longer than preanal one, with preanal portion only slightly times longer than anal one. Preanal and postanal angles weakly defined. Postanal margin of postabdomen provided with 6-8 marginal denticles. Anal margin with 2 clusters spinules in distal portion. 10-12 lateral fascicles of setules, distal setules in fascicle being longest. Postabdominal claw of moderate length, 1.5 times longer than preanal portion of postabdomen. Basal spine ca 0.25 of length of claw.

Antennule with longest aesthetasc of ca $1 / 2$ length of antennule. Exopodite III with seta 6 of about $2 / 3$ length of seta 3 . Exopodite IV with seta 3 being longest, setae $1-2$ slightly shorter, setae $4-6 \mathrm{ca} 2 / 3$ length of seta 3 .

\section{Male}

Unknown. 


\section{Differential diagnosis}

Flavalona weltneri comb. nov. differs from all members of the costata-clade by its postabdomen with obtuse distal angle and no incursion between base of claws and distal margin, and by a longer basal spine of postabdominal claw, about 0.25 of claw length, 1.5 times the width of the claw base.

\section{Type material}

\section{Holotype}

Adult parthenogenetic , in Museum für Naturkunde, Berlin, no. 18948.

\section{Type locality}

POLAND: Madü-See (=Jezioro Miedwie), Pyrzyce (Pyritz), West Pomerania.

\section{Distribution}

Switzerland, Germany, Poland, Norway, Sweden and Finland (Van Damme et al. 2011).

\section{Rustica-clade}

Characteristic features of the rustica-clade clade include: (1) valves with weakly developed linear or tubercular sculpture; (2) anterior group of setae on valves with longest setules in posterior part of the group; (3) short lateral head pores with small pockets, length of pore less than 0.5 IP. (4) postabdomen with prominent rounded distal angle; (5) lateral fascicles of setules on postabdomen with middle setae being longest; (6) male postabdomen with long genital process, its length over $1 \frac{1}{2}$ length of claw. Species of rustica-group have a thicker cuticle than the costata-clade, and more thick, spine-like short setules on antenna and limb I. Species of the rustica-clade frequently retain valves from the 1-2 previous molts, a situation never recorded in the costata-clade.

The rustica-clade is less uniform than the costata-clade. Species of the group differ in size, morphology of posteroventral angle of valves, length of rostrum, morphology and position of major head pores, labrum, armament of postabdomen, morphology of scrapers on limb II, proportions of setae of exopodite III and shape of exopodite V. Male morphology is known for four taxa, viz. F. rustica rustica comb. nov., F. rustica americana comb. nov., F. iheringula comb. nov. and F. bicolor comb. nov., differing in shape of postabdomen, morphology of postabdominal claw and length of its distal setules.

Flavalona rustica (Scott, 1895) comb. nov.

Flavalona rustica rustica (Scott, 1895) comb. nov.

Figs 4-5

Alona rustica Scott, 1895: 189-190, pl. 5, figs 5, 17.

Alona estonica Maëmets, 1958: 260-264, figs 1-3, photos 1-2.

Alona rustica - Frey 1965: 162-169, figs 1-7. - Flössner 1967: 443-444, fig. 2. - Smirnov 1971: 360-363, figs 416-418. — Flössner 1972: 301-304, fig. 142. — Van de Velde \& Dumont 1978: 306, fig. 1A-C. - Dumont 1983: 102-105, pl. 4. - Negrea 1983: 228-190, fig. 117. - Margaritora 1985: 316-318, fig. 125. — Alonso 1996: 323-325, fig. 144. — Flössner 2000: 318, fig. 118. — Margaritora \& Vagaggini 2002: 61-59, figs 1-10. — Sinev 1999a: 146, fig. 10. — Sinev 2001: 118, figs 26-34. Sinev 2002: 396, figs 3д,о, 4д, 5и. — Hudeč 2010: 322-324, fig. 78.

Alona estonica - Maëmets 1960: 35-40, fig. 1, photos 1-2. 

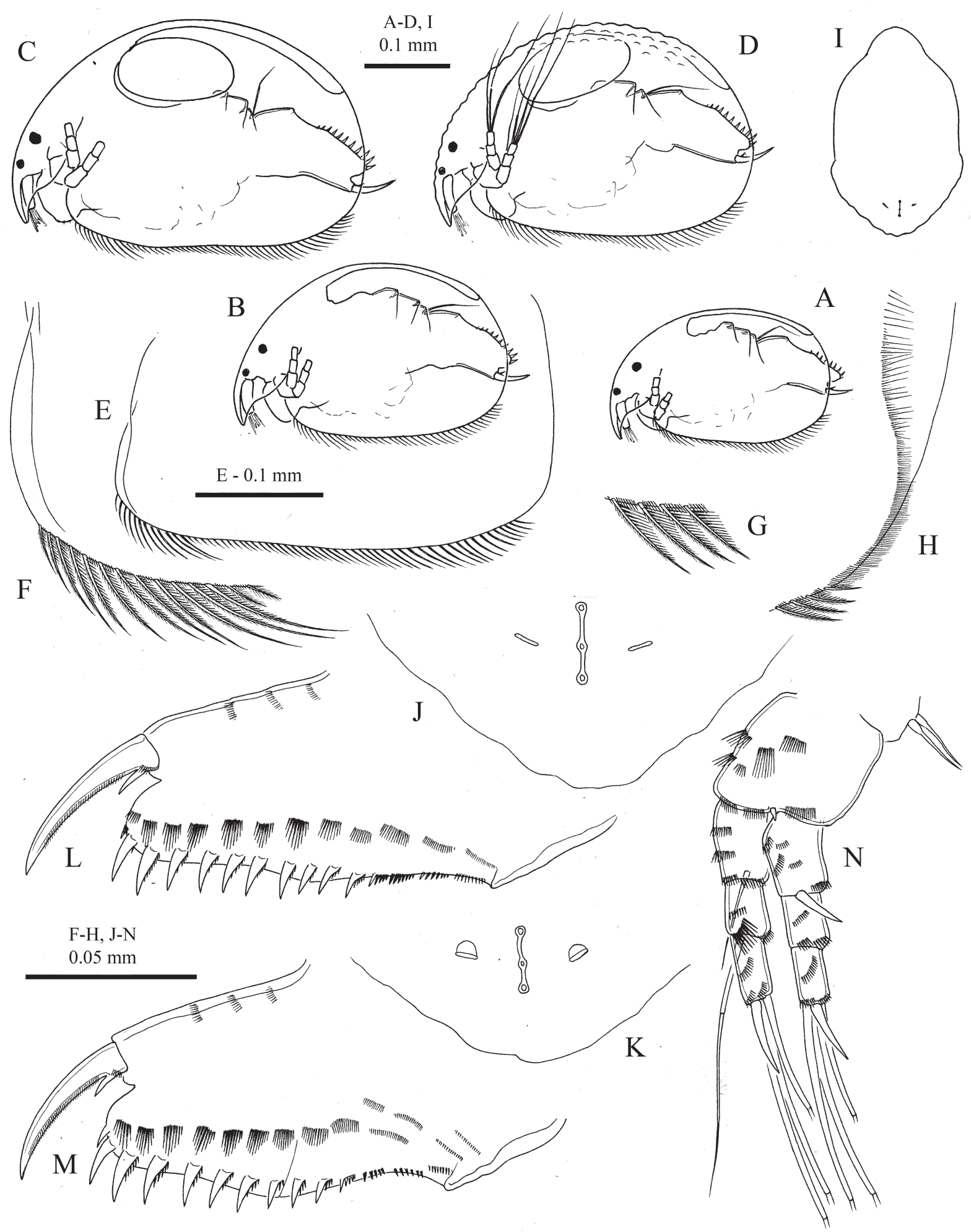

Fig. 4. Flavalona rustica (Scott, 1895) comb. nov. from Bol'shoe Torfyanoe lake, Bolshoi Solovetskiy Island (White Sea), Russia. A-B. Juvenile $q$ + $\propto$ of instars I and II. C-N. Parthenogenetic + . C. Specimen with oblique valves. D. Specimen with tuberculated valves. E. Ventral margin of valves. F. Anterior setae of valves. G. Posterior setae of valves. H. Posteroventral corner and posterior margin of valves. I. Head shield. J-K. Head pores. L-M. Postabdomen. N. Antenna. 

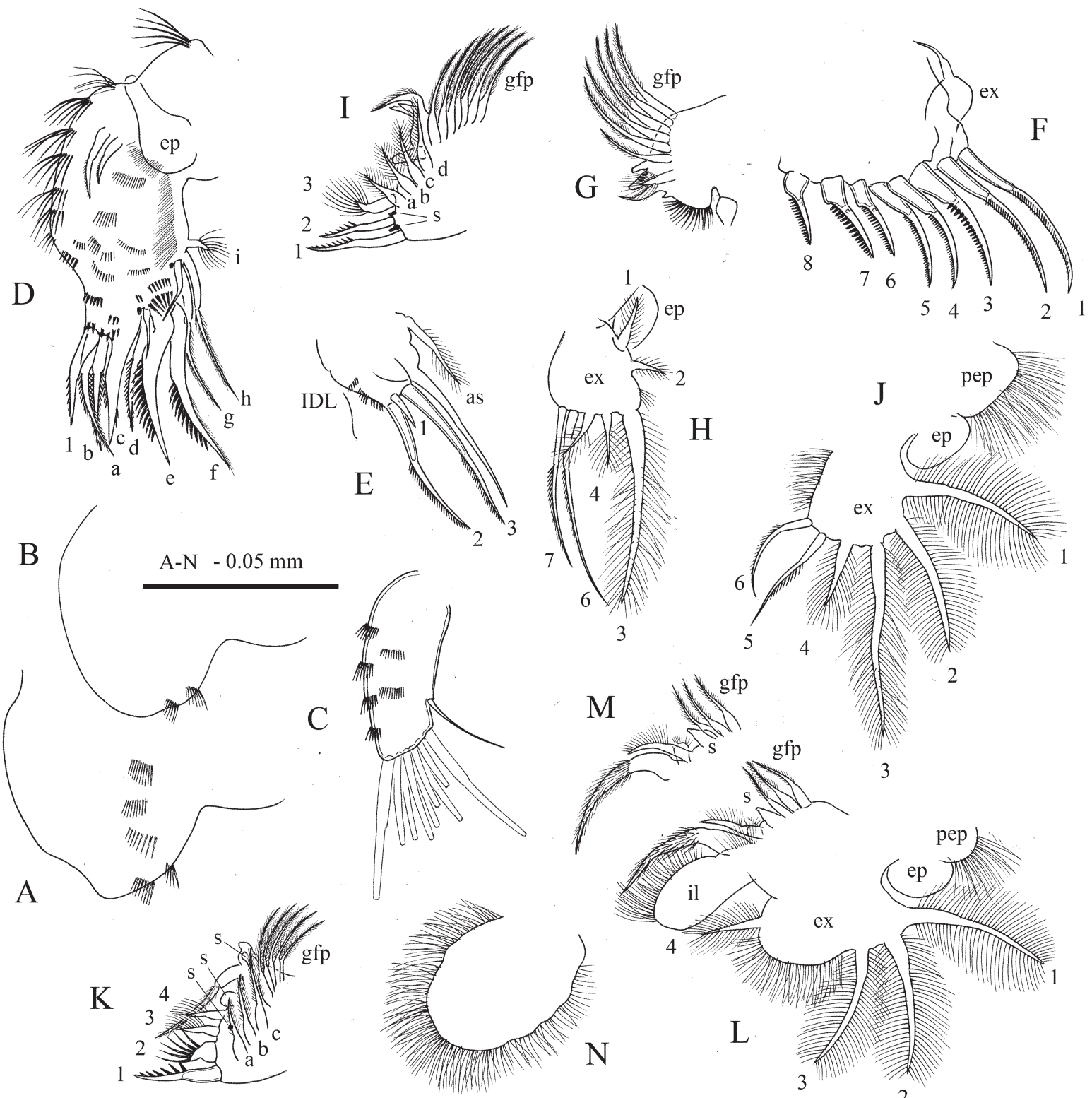

$\mathrm{E}$
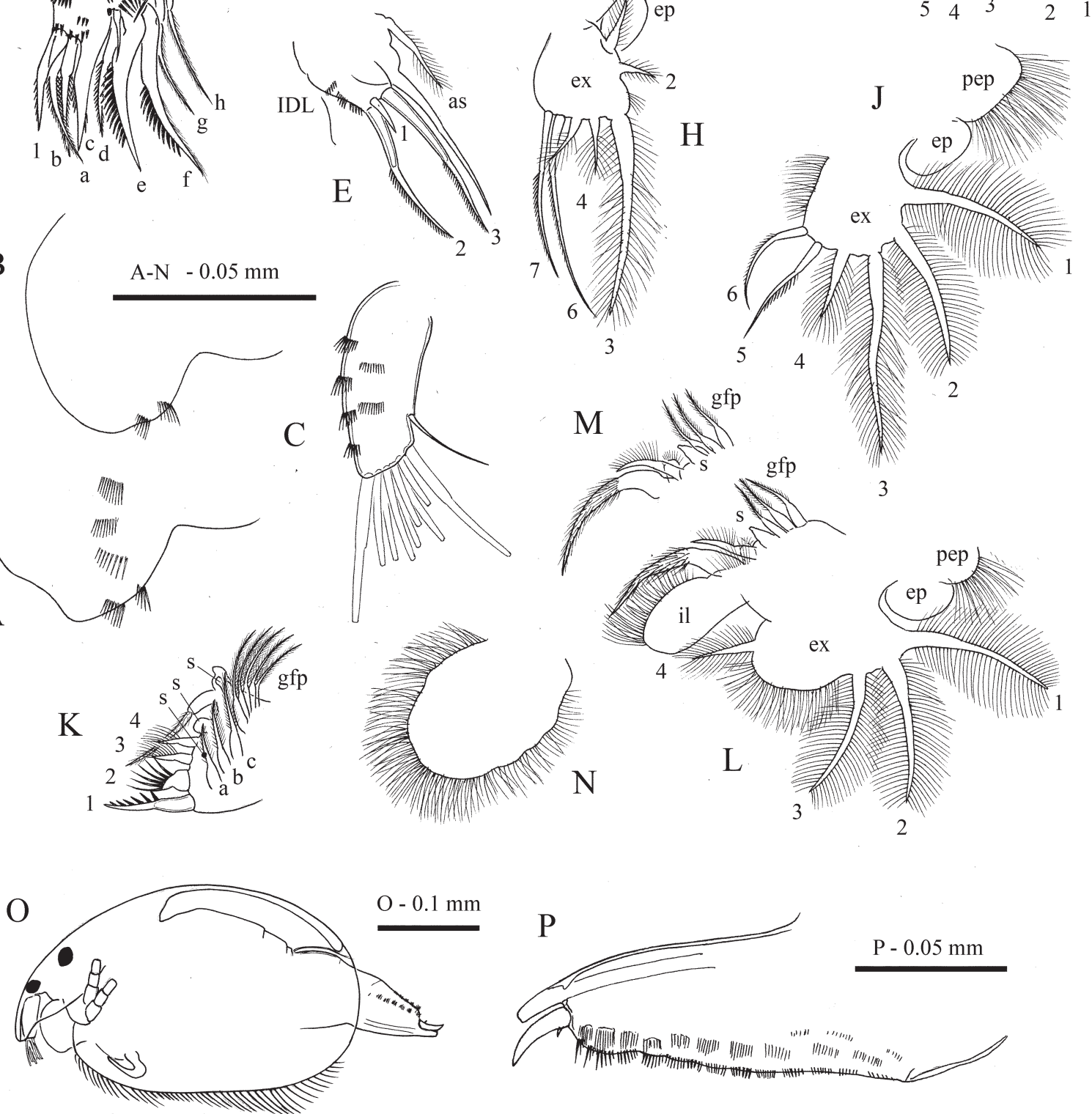

Fig. 5. Flavalona rustica (Scott, 1895) comb. nov. A-N. Labrum, antennule and thoracic limbs of parthenogenetic $\&$ from Bol'shoe Torfyanoe lake, Bolshoi Solovetskiy Island (White Sea), Russia. A-B. Labrum. C. Antennule. D. Limb I. E. IDL and ODL of limb I. F. Scrapers of limb II. G. Gnathobase of limb II. H. Exopodite of limb III. I. Inner portion of limb III. J. Exopodite of limb IV. K. Inner portion of limb IV. L. Limb V. M. Gnathobase of limb V. N. Limb VI. O-P. Adult J . O. Lateral view. P. Postabdomen. Figure O redrawn from Alonso (1996) and P from Sinev (1999a). 


\section{Differential diagnosis}

Flavalona rustica rustica comb. nov. differs from F. iheringula comb. nov. by its middle major head pore located halfway between the posterior and anterior pores and by the oval, an unbilobed exopodite of limb V, from F. sphagnophila comb. nov. by its transverse, not dot-like lateral head pores and by an oval, not bilobed exopodite of limb V, from F. bicolor comb. nov. by a smaller size, short rostrum and labral keel without denticles, from $F$. hudeci comb. nov. by a smaller size, presence of numerous setules on posteroventral corner of valves, and by seta 6 of exopodite III almost as long as seta 3 . Male of F. rustica comb. nov. differs from F. iheringula comb. nov. and F. bicolor comb. nov. by marginal setules of postabdomen in distal groups of moderate length, little more than width of postabdominal claw base (in F. iheringula comb. nov. they are short, less than width of postabdominal claw base, and in F. bicolor comb. nov. they are long, about two postabdominal claw bases).

We provide a full description of $F$. rustica comb. nov. as typical of the rustica-clade.

\section{Type material}

Non-existent.

\section{Material studied here}

Four parthenogenetic 우 $ᄋ$ from Lake Motjønn, west coast of Nisser Lake, Norway, 59 $08.62^{\prime} \mathrm{N}$, $8^{\circ} 27.32^{\prime}$ E, 4 Oct. 2015, coll. A. Y. Sinev \& B. Walseng; 47 parthenogenetic $q+q$ from Bol'shoe Torfyanoe lake, Bolshoi Solovetskiy Island (White Sea), Russia, 24 Jul. 1997, coll. A. Evseev; 12 parthenogenetic 우 from Karelia Republic, Russia, exact location unknown, from collection of N.N. Smirnov.

\section{Type locality}

Scotland.

\section{Description}

\section{Parthenogenetic female}

Length of adult $0.35-0.52 \mathrm{~mm}$. In lateral view body (Fig. 4A-D) regular oval or slightly ovoid, maximum height at mid-body or somewhat behind it, height-length ratio ca 0.6-0.65. Dorsal margin uniformly curved. Postero-dorsal and postero-ventral angles broadly rounded. Posterior margin uniformly curved. Ventral margin (Fig. 4E) almost straight, with about 50-60 setae, about 12 first setae long, next 15 setae short, other setae of moderate length. Setae of anterior group (Fig. 4F) longer than of posterior group (Fig. $4 \mathrm{G}$ ), posteriormost seta of group the longest. Groups of small setules located between bases of all ventral setae. Posteroventral angle (Fig. $4 \mathrm{H}$ ) with ca 50 long setules protruding beyond margin of valves. A row of about 150 setules along posterior margin on inner side of carapace. Sculpture of carapace either thin, weakly developed longitudinal lines without striae, or rows of tubercles (Fig. 4D).

Head relatively small, triangular-round in lateral view, rostrum short, pointing downward. Eye larger than ocellus. Distance from tip of rostrum to ocellus greater than between ocellus and eye.

Head shield (Fig. 4I) with maximum width behind mandibular articulation, without any sculpture in specimens with linear sculpture of valves, or covered by tubercles. Rostrum more elongated than in costata-clade, broadly rounded. Posterior margin of head shield broadly rounded, wavy in tuberculated specimens. Three major head pores (Fig. 4J-K) with thin connection between them, middle pore slightly smaller than others, located at the middle PP about 1-1.5 IP. Transverse lateral head pores of about 0.3-0.4 IP length, located about 0.5 IP distance from midline, at a level between anterior and middle main head pores. Lateral pore pockets semicircular, with depth ca $0.5-0.9$ pore lengths. 
Labrum of moderate size (Fig. 5A-B). Distal labral plate without setulation. Labral keel of moderate width, with a blunt or rounded apex. Anterior margin of keel convex, posterior margin with two clusters of setules. Clusters of lateral setules observed in anterior half of the keel in some specimens.

Thorax and abdomen subequal in length, dorsal surface of abdominal segments not saddle-shaped. Second abdominal segment with two transverse rows of short setules.

Postabdomen (Fig. 4L-M) wide, narrowing distally, with a prominent broadly rounded distal angle, length ca 2.0-2.3 height. Ventral margin straight. Inflated basis of claws bordered from distal margin by clear incision. Distal margin strongly convex. Dorsal margin with distal part about 2.5 times longer than preanal part, with postanal portion about 1.3-1.5 times longer than anal one. Postanal and anal portions of distal margin weakly concave. Preanal angle well-defined, postanal angle weakly defined. Preanal margin almost straight. Postanal portion of postabdomen with 7-8 well developed composite marginal denticles, each with several spinules on anterior margin, anal portion with 2-3 marginal denticles, similar to postanal ones, and with 2-3 groups of thick setules. Length of denticles decrease basally, length of longest denticles about 1.5 widths of postabdominal claw base. Ten-twelve lateral fascicles of thin setules; in postanal fascicles middle seta being longest, 1.5 times shorter than marginal denticles. Postabdominal claw of moderate length, somewhat longer than preanal portion of postabdomen. Basal spines short, their length less than width of postabdominal claw base.

Antennule (Fig. 5C) of moderate length, not reaching the tip of rostrum, with four transverse rows of short thick setules at anterior face. Antennular sensory seta slender, 2 times shorter than antennule, arising at $2 / 3$ distance from the base. Nine aesthetascs, two of which longer than others, of about $3 / 4$ length of antennule, others of similar length.

Antenna (Fig. 4N) of moderate length. Antennal formula, setae $0-0-3 / 1-1-3$, spines $1-0-1 / 0-0-1$. Basal segment robust, branches elongated, slender, all segments cylindrical, with short setules around distal margin and groups of thick lateral setules. Seta arising from basal segment of endopodite short and thin, not reaching tip of distal segment. Seta arising from middle segment of endopodite of similar size with apical setae. Spine on basal segment of exopodite shorter then middle segment. Apical spines slightly longer than respective apical segments.

Thoracic limbs six pairs.

LimB I (Fig. 5D-E). Epipodite oval, with finger-like process as long as epipodite itself. Accessory seta about half the length of ODL. IDL with three setae and clusters of setules on ventral surface, IDL seta 1 small, thin, setae 2 and 3 subequal in length to ODL seta, both with thin setules in distal part. Endite 3 with inner seta (1) shorter than outer $(\mathrm{a}-\mathrm{c})$. Endite 2 with three outer setae $(\mathrm{d}-\mathrm{f})$ and short inner seta (2) and sensillum near its base, setae $\mathrm{e}-\mathrm{f}$ short, about half length of limb, seta $\mathrm{f}$ slightly longer than seta e. Endite 1 with inner seta (3) longer than inner seta of endite 2 and sensillum near its base, two 2-segmented setae $(\mathrm{g}-\mathrm{h})$, both setulated in distal part, and a flat seta (i) of characteristic shape, with shortened distal portion, armed with long setules. Seven rows of thin long setules on ventral face of limb. Two ejector hooks, one of them 1.5 times longer than the other. Maxillar process elongated, with single seta.

LimB II (Fig. 4F-G). Exopodite oval, with seta almost as as long as exopodite. Eight scraping spines, scrapers 1-5 long, scrapers 6-8 much shorter, armed with small setules. Scrapers 3 and 6 of similar length as its neighbours, but thicker and armed with thicker setules. Distal armature of gnathobase with four elements. Filter plate with seven setae, posteriormost seta considerably shorter and thicker than other, armed with long setules, next seta of same morphology with others, but two times shorter. 
LimB III (Fig. 4H-I). Epipodite oval, without process. Exopodite (Fig. 3I) trapezium-shaped, with seven setae. Seta 3 being longest, setae 6 almost as long as seta 3, seta $7 \mathrm{ca} 3 / 4$ the length of seta 3 , other setae short. Setae 6 and 7 unilaterally armed with short setules in distal portion, all other setae flat, plumose, setules on seta 3 considerably longer than on short setae. Distal endite with three setae, two distalmost members (1-2) slender, sharp, of similar length, with distal parts unilaterally armed thick sharp denticles; basalmost seta (3) thicker, bilaterally armed with long setules. Basal endite and gnathobase as with four plumose outer setae $(\mathrm{a}-\mathrm{d})$, increasing in size in basal direction. Four inner setae (4-7) increasing in size basally, a small sensillum near the base of distalmost seta (4). Distal armature of gnathobase with four elements. The first one elongated, cylindrical sensillum, second thin, bent seta, others two - blunt spines with fused bases. Filter plate III with seven setae.

LimB IV (Fig. 5J-K). Pre-epipodite setulated; epipodite without process. Exopodite quadrangular, with six setae. Seta 3 being longest, seta $1-2$ slightly about $3 / 4$ length of seta 3 , setae 4 ca $1 / 3$ the length of seta 3, setae 5-6 cahalf length of seta 3. Setae 1-4 flat, plumose, setae 5-6 slender, unilaterally armed with short setules in distal portion. Inner-distal portion of limb IV with four setae and small rounded sensillum. Seta 1 slender, sharp, armed with long spinules. Distal flaming-torch seta (2) of typical for Aloninae shape, broad, with curved distal portion, armed with about 6 long thick setules. Two other flaming-torch setae (3-4) thin and straight, with straight distal portion, armed with very thin, hairlike setules, a small sensillum located near their bases. Three inner setae $(a-c)$ long, increasing in size basally. Gnathobase with a short 2-segmented seta, only little longer than seta 1, and hillock with sensilla distally. Filter plate with five setae.

LimB V (Fig. 5L-M). Pre-epipodite setulated, epipodite without process. Exopodite oval, with 4 plumose setae. Seta 1 being longest, setae 2-3 slightly shorter than seta 1 , seta 4 two times shorter than seta 1 . Inner limb portion an elongated oval lobe, with setulated inner margin. At inner face, two setae, one three times longer than other, and a triangular sensillum. Filter plate with three setae.

LimB VI (Fig. $5 \mathrm{~N}$ ) an oval lobe, its length about 1.3 times its maximum width, densely setulated along all of its margin.

Description of ephippial females and males taken from the literature (Alonso 1996; Hudeč 2010).

\section{Ephippial female}

Outline similar to that of parthenogenetic female, dorsal margin more highly arched in most specimens. Ephippium in preserved specimens yellow-brown. Ephippium without sculpture.

\section{Adult male}

Length up to $0.39 \mathrm{~mm}$. Body low oval (Fig. 5O), dorsal margin weakly convex. Maximum height at midbody, height/length ratio about 0.55 . Ocellus larger than in female. Rostrum short, slightly truncated.

Postabdomen (Fig. 5P) moderately long, narrowing distally in postanal part. Ventral margin straight or wavy. Basis of claws bordered from distal margin by clear incision. Genital process long, about $2 / 3-3 / 4$ length of postabdominal claw. Distal margin concave, distal angle brioadly rounded, weakly prominent. Dorsal margin weakly concave in anal and in postanal portions. Preanal angle not defined, postanal angle weakly defined. Clusters of setules in place of marginal denticles, distalmost clusters consisting of numerous long setules, their length exceed width of postabdominal claw. Lateral fascicles of setules as in female. Postabdominal claw 2 times shorter than preanal portion of postabdomen, weakly curved. Basal spine short and thick. 
Antennule shorter and broader than in female, with 12 terminal aesthetascs, longest almost as long as antennule, shortest about $1 / 2$ length of antennule. Male seta arising at $1 / 4$ length from tip, about $1 / 3$ length of antennule.

Thoracic limb I (Fig. 3) with U-shaped copulatory hook, half as long as limb itself. IDL with three setae, IDL seta 1 absent. IDL setae 2 and 3 much thinner and two times shorter than in female, of similar length. Male seta curved, slightly shorter than seta 2. Copulatory brush seta about half length of IDL seta 2. Ventral surface of limb under copulatory brush with row of 20 stiff setules.

\section{Distribution}

Azores (Van de Velde \& Dumont 1978), Europe and Siberia (Smirnov 1971). Bryophilic, typical of acid bogs with Sphagnum L., 1853, not found in neutral and alkaline waters. In Central and Southern Europe confined to mountainous regions. The only Flavalona gen. nov. species found in subterraneous waters (Dumont 1983; Sabater 1987).

Flavalona rustica americana (Flössner \& Frey, 1970) comb. nov.

Alona rustica americana Flössner \& Frey, 1970: 326-328, figs 1-2, 5.

\section{Differential diagnosis}

Flavalona rustica americana comb. nov. differs from the nominal subspecies in the morphology of the male postabdomen, which lacks the basal spine on the postabdominal claw and has wider clusters of distal setules.

\section{Type material}

\section{Holotype}

q in the Natural History Museum, London, United Kingdom, no. 1969.5.27.1.

\section{Allotype}

$\lesssim$ in the Natural History Museum, London, United Kingdom, same number.

\section{Type locality}

UNITED STATES OF AMERICA: Channel between Martin and Oliver lakes, La Grange Co., Indiana.

\section{Distribution}

Canada and U.S.A. Flössner \& Frey (1970) considered all North American populations of Flavalona rustica comb. nov. belonging to F. rustica Americana comb. nov..

Flavalona bicolor (Frey, 1965) comb. nov.

Fig. 6A-F

Alona bicolor Frey, 1965: 169-170, fig. 23-29.

Alona bicolor - Frey 1969: 380-386, fig. 1-6. — Smirnov 1971: 363-365, fig. 421 - Sinev 2009: 60-65, fig. 1-3.

\section{Diagnosis}

\section{Female}

Length of adult $0.50-0.62 \mathrm{~mm}$. Body (Fig. 6A) regular oval, maximum height at the middle of body, height/length ratio about $0.65-0.72$. Valves from previous molts often retained. Posteroventral angle 


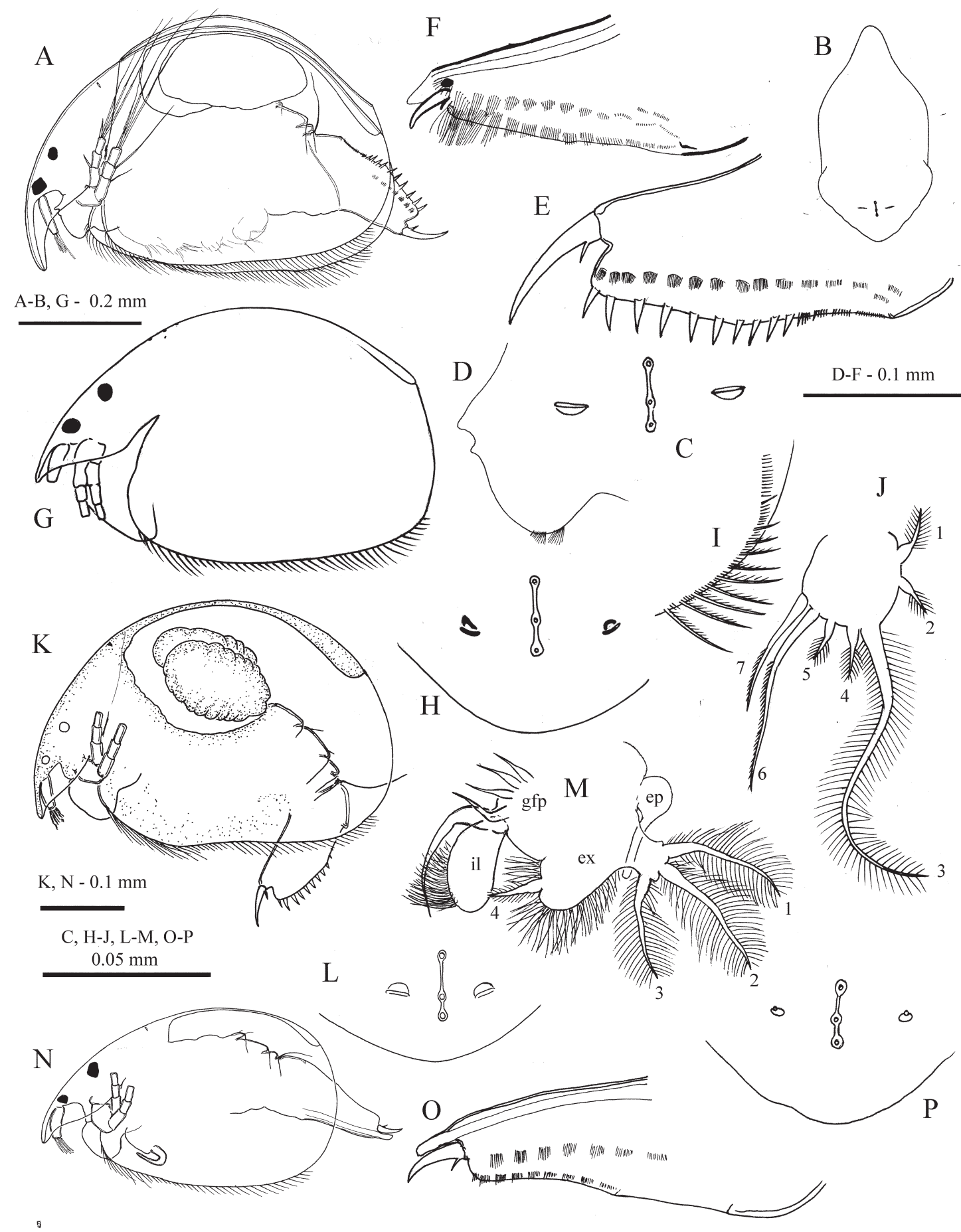

Fig. 6. Flavalona bicolor (Frey, 1965) comb. nov. A-E. Parthenogenetic 9 . A. Lateral view (specimen retaining valves from previous moult). B. Head shield. C. Head pores. D. Labrum. E. Postabdomen. F. Postabdomen of adult $\hat{\jmath}$. - G-J. Flavalona hudeci (Sinev, 1999) comb. nov., parthenogenetic o G. Lateral view. H. Head pores. I. Posteroventral corner of valves. J. Thoracic limb V. $-\mathbf{K}-\mathbf{O}$. Flavalona iheringula (Sinev \& Kotov, 2004) comb. nov. K-M. Parthenogenetic 9 . K. Lateral view. L. Head pores. M. Thoracic limb V. N-O. Adult $\delta^{\Uparrow}$. N. Lateral view. O. Postabdomen. - P. Flavalona sphagnophila (Van Damme \& Eggermont, 2011) comb. nov., parthenogenetic $\$$, head pores. Figures A-F from Sinev (2009), G-J redrawn from Hudeč (1998), K-M from Sinev (2001), N-O from Kotov \& Sinev (2004) and P redrawn from Van Damme \& Eggermont (2011). 
without setules protruding beyond valve margins. Ventral margin with ca 60 setae. Valves without sculpture.

Eye smaller than ocellus. Rostrum elongated, about 1.5-2 length of antennule, with rounded apex. Posterior margin of head shield (Fig. 6B) triangular with rounded apex. Three major head pores (Fig. 6C) of similar size, middle pore located closer to posterior pore. Connection between pores narrow. PP about 2 IP. Lateral head pores of about 0.4 IP length, lateral pore pockets shallow, with depth about $1 / 4$ of pore length. Labral keel (Fig. 6D) with 1-2 denticles on anterior margin.

Postabdomen (Fig. 6E) truncated, length less than 2.5 height. Distal margin convex, distal angle prominent, rounded. Dorsal margin weakly convex in preanal part, concave in anal part, and almost straight in postanal part. Distal part of dorsal margin 3 times longer than preanal one, anal and preanal portions of similar length. Preanal and postanal angles weakly defined. Postanal margin of postabdomen provided with 6-7 marginal denticles. Anal margin with 3-4 more slender denticles and 3-4 clusters of marginal setules. 10-14 lateral fascicles of setules, central setules in fascicle being longest. Postabdominal claw 1.5-1.7 times longer than preanal portion of postabdomen. Basal spine short, robust, about 0.15 length of claw itself.

Antennule with longest aesthetasc as long as antennule. Limb II with scrapers 3 and 7 thicker and armed with more robust denticles than other. Exopodite III with seta 6 of about $2 / 3$ length of seta 3 . Exopodite IV with seta 3 being longest, setae 1-2 slightly shorter, setae 4-6 about half length of seta 3, seta 4 longer than setae 5-6. Epipodites IV-V without processes. Exopodite V oval.

\section{Male}

Length $0.51-0.53 \mathrm{~mm}$. Body low oval, height/length ratio ca $0.55-0.59$. Ocellus larger than eye. Postabdomen (Fig. 6F) evenly truncated. Preanal and postanal angles not defined. Distal part of postabdomen 3.5 times longer than preanal. Distal process long, ca $2 / 3-3 / 4$ length of claw. Distal clusters of marginal setules long, about two widths of postabdominal claw base. Postabdominal claw short, basal spine short, about 0.1 length of claw.

\section{Differential diagnosis}

Flavalona bicolor comb. nov. differs from all other species of the rustica-clade by an elongated rostrum, an ocellus larger than the eye, labral keel with blunt denticles and large IP/PP ratio (about 2). Males differ by their large size and long distalmost marginal setules at the end of the postabdomen.

\section{Type material}

Holotype

Parthenogenetic female, British Museum (Nat. Hist.), London, 1963.6.24.1.

\section{Material studied earlier}

See Sinev (2009) for list of material from the U.S.A.

\section{Type locality}

UNITED STATES OF AMERICA: Goodwill Pond, Barnstable County, Massachusetts.

\section{Distribution and ecology}

Flavalona bicolor comb. nov. inhabits East Canada and North-East U.S.A. (Sinev 2009). According to Chengalath $(1982,1987)$, it is not found west of the Ontario- Manitoba border. It is found only in areas with rocky or sandy bottom, and is more rare than $F$. cf. rustica and $F$. cf. costata. 
Flavalona hudeci (Sinev, 1999) comb. nov.

Fig. 6G-J

Alona hudeci Sinev, 1999: 147.

Alona rusticoides - Hudeč, 1998: 205-207, figs 1-8, 23-31.

Diagnosis (from Hudeč 1998)

\section{Female}

Length of adult up to $0.7 \mathrm{~mm}$. Body regular oval (Fig. 6G), maximum height at mid-body, height/ length ratio about 0.62 .Valves from previous molts not retained. Posteroventral angle without setules protruding beyond valve margins (Fig. 6I). Valves oblique or with weak polygonal reticulation.

Eye and ocellus of similar size. Rostrum short, broadly rounded. Posterior margin of head shield broadly rounded. Three major head pores (Fig. $6 \mathrm{H}$ ) of same size, middle pore located slightly closer to posterior pore. Connection between pores narrow. PP about 0.8 IP. Lateral head pores of about 0.25 IP length, lateral pore pockets shallow, with depth about $1 / 3$ of pore length. Labral keel without denticles on anterior margin.

Postabdomen truncated, length about 2.3 heights. Distal margin convex, distal angle prominent, broadly rounded. Dorsal margin weakly convex in preanal part, concave in anal part, straight in postanal part. Distal part of dorsal margin 3 times longer than preanal one. Preanal angle well-defined, postanal angle not defined. Margin of postabdomen provided with 9-11 marginal denticles and 3-4 clusters of marginal setules. About 10 lateral fascicles of setules, middle setules in fascicle being longest. Postabdominal claw 1.3 times longer than preanal portion of postabdomen. Basal spine about 0.15 of length of claw.

Antennule with longest aesthetasc of about $2 / 3$ length of antennule. Scrapers of limb II of similar morphology. Exopodite III (Fig. 6J) with seta 6 of about $2 / 3$ length of seta 3 . Exopodite IV with seta 1 being longest, setae 2-2 slightly shorter, setae 4-5 about half length of seta 1, setae 6 longer than setae $4-5$, about $4 / 5$ length of seta 1 . Epipodites IV-V with processes about 1.5 of epipodite length. Exopodite V bilobed.

\section{Male}

Unknown.

\section{Differential diagnosis}

Flavalona hudeci comb. nov. differs from F. bicolor comb. nov. by a short rostrum, ocellus smaller than eye, and labral keel without denticles; from all other species of the rustica-branch - by its large size, absence of setules on posteroventral corner of valves, and by seta 6 of exopodite III only ca $2 / 3$ as long as seta 3 .

\section{Type material}

\section{Holotype}

Parthenogenetic $q$, British Museum (Natural History), No. 1998.784.

\section{Paratypes}

Parthenogenetic 40 \& 9 from the type locality at the British Museum (Natural History), nos 1998.785795, 1998.796-797, 1998.798-810, 1998.811-825. 


\section{Type locality}

WEST VENEZUELA-BRAZIL: small rock pool on Roraima Tepui (= table mountain).

\section{Distribution}

Recorded from a humic-water rock-pool on Roraima tepui in Venezuela (Hudeč 1998).

Flavalona iheringula (Kotov \& Sinev, 2004) comb. nov.

Fig. $6 \mathrm{~K}-\mathrm{M}$

Alona iheringi Sars, 1901: 49-51, plate IX, fig. 2a-c.

Alona iheringula Kotov \& Sinev, 2004: 96-98, figs 1-8.

Alona iheringi - Sinev 2001: 114-118, figs 1-25.

Alona iheringula - Van Damme \& Dumont 2010: 764, fig. 6.

non Alona iheringula - Silva et al. 2014: 2-5, fig. 1.

\section{Diagnosis}

\section{Female}

Length $0.38-0.45 \mathrm{~mm}$. Body oval (Fig. $6 \mathrm{~K}$ ), maximum height at mid-body, height/length ratio ca 0.62 0.65 . Valves from previous molts retained by some specimens. Posteroventral angle with about 50 setules protruding beyond valve margins. Ventral margin with about 60 setae. Valves without sculpture or tubercles.

Eye smaller than ocellus. Rostrum short. Posterior margin of head shield broadly rounded. Three major head pores (Fig. 6L) of similar size, middle pore located closer to posterior pore. Connection between pores narrow. PP ca $0.5-0.7$ IP. Lateral head pores of ca 0.3 IP length, lateral pore pockets shallow, semicircular, with depth about half length of pore. Labral keel without denticles on anterior margin.

Postabdomen truncated, length about 2.2-2.4 height. Distal margin convex, distal angle prominent, rounded. Dorsal margin weakly convex in preanal part, concave in anal part, and almost straight in postanal part. Distal part of dorsal margin 2.5 times longer than preanal one, with preanal portion 1.5 times longer than anal. Preanal angle well-defined, postanal angle weakly defined. Postanal margin of postabdomen with 7-8 marginal denticles. Anal margin with 2-3 more slender denticles and 2-3 clusters of marginal setules. 10-12 lateral fascicles of setules, central setules in fascicle the longest. Postabdominal claw 1.3 times longer than preanal portion of postabdomen. Basal spine short, robust, ca 0.2 lengths of claw.

Antennule with longest aesthetasc ca $2 / 3$ length of antennule itself. Limb II with scrapers 3 and 7 only slightly thicker than other. Exopodite III with seta 6 almost as long as seta 3. Exopodite IV with seta 1-3 of similar length, setae 4 about $1 / 3$ length of seta 3 , setae $5-6$ about $2 / 3$ length of seta 3 . Epipodites IV-V with long processes. Exopodite V strongly bilobed (Fig. 6M).

\section{Male}

Length $0.34 \mathrm{~mm}$. Body low ovoid (Fig. 6N), height/length ratio ca 0.58 . Ocellus larger than eye. Postabdomen (Fig. 6O) evenly truncated. Pre- and postanal angles not defined. Distal part of postabdomen 2.5 times longer than preanal. Distal process long, about $2 / 3$ length of claw. Distal clusters of marginal setules short. Postabdominal claw short, basal spine short and thin, slightly shorter than claw. 


\section{Differential diagnosis}

Flavalona iheringula comb. nov. differs from F. rustica rustica comb. nov. and F. rustica americana comb. nov. by the middle major head pore located closest to the posterior pore and by the strongly bilobed exopodite of limb V; from F. bicolor comb. nov. by a smaller size, short rostrum and labral keel without denticles; from $F$. hudeci comb. nov. by a smaller size, presence of numerous setules on posteroventral corner of valves, and by seta 6 of exopodite III almost as long as seta 3, and from F. sphagnophila comb. nov. by having transverse lateral head pores. Male $F$. iheringula comb. nov. differ from $F$. bicolor comb. nov. and F. rustica comb. nov. by shorter distal marginal setules on the postabdomen.

\section{Type material}

\section{Lectotype}

Adult parthenogenetic female, Zoological Museum of Oslo University, F12336a.

\section{Paralectotypes}

See Kotov \& Sinev (2004) for a full list.

\section{Material studied earlier}

See Sinev (2001) and Kotov \& Sinev (2004) for a list of material from Brazil.

\section{Type locality}

BRAZIL: São Paulo.

\section{Distribution}

Widely distributed in Brazil (Elmoor-Loureiro 2015), but not yet recorded outside of the country.

Flavalona sphagnophila (Van Damme \& Eggermont, 2011) comb. nov.

Fig. 6P

Alona sphagnophila Van Damme \& Eggermont, 2011: 71-75, figs 4-5.

Diagnosis (from Van Damme \& Eggermont 2011)

\section{Female}

Length of adult $0.42-0.48 \mathrm{~mm}$. Body regular oval, maximum height at mid-body, height/length ratio ca $0.62-0.65$. Valves from previous molts not retained. Posteroventral angle with about 50 setules protruding beyond valve margins. Ventral margin with about 70 setae. Valves without sculpture or tubercles.

Eye smaller than ocellus. Rostrum short. Posterior margin of head shield broadly rounded. Three major head pores (Fig. 6P) of similar size, middle pore located closest to posterior pore. Connection between pores narrow. PP ca 0.6-0.8 IP. Lateral head pores short, rounded, about to 0.1 IP length, lateral pore pockets round, their diameter over 3 lengths of pore. Labral keel without denticles.

Postabdomen truncated, length ca 2.0-2.5 height. Distal margin convex, distal angle prominent, rounded. Dorsal margin weakly convex in preanal part, concave in anal part, and almost straight in postanal part. Distal part of dorsal margin 2.5 times longer than preanal one, with preanal portion 1.5 times longer than anal. Preanal angle well-defined, postanal angle weakly defined. Postanal margin of postabdomen provided with 7-8 marginal denticles, length of denticle strongly decrease basally. Anal margin with 2-3 more slender denticles and 2-3 clusters of marginal setules. 10-12 lateral fascicles of setules, 
central setules in fascicle being longest. Postabdominal claw 1.3 times longer than preanal portion of postabdomen. Basal spine short, robust, ca 0.2 length of claw.

Antennule with longest aesthetasc as ca $2 / 3$ length of antennule itself. Limb II with scrapers 3 and 7 only slightly thicker than other. Exopodite III with seta 6 as long as seta 3. Exopodite IV with seta 1-3 of similar length, setae 4 ca $\frac{1}{3}$ length of seta 3 , setae $5-6$ about $1 / 2$ length of seta 3 . Epipodites IV-V with long processes. Exopodite V strongly bilobed.

\section{Male \\ Unknown.}

\section{Differential diagnosis}

Flavalona sphagnophila comb. nov. differs from all species of the group by short, rounded lateral pores with pocket diameter over 3 pore lengths. It differs from F. rustica rustica comb. nov. and F. rustica americana comb. nov. by the middle head pore located closer to the posterior pore and by the strongly bilobed exopodite of limb V; from F. bicolor comb. nov. by its smaller size, short rostrum and labral keel without denticles; from $F$. hudeci comb. nov. by a smaller size, presence of numerous setules on the posteroventral corner of the valves, and by seta 6 of exopodite III almost as long as seta 3 .

\section{Type material}

\section{Holotype}

A parthenogenetic 9 , Royal Belgian Institute of Natural Sciences, IG.31.685.

\section{Paratypes}

Seven parthenogenetic $ㅇ$, , Royal Belgian Institute of Natural Sciences, IG. 31.685.

\section{Type locality}

UGANDA: Lake Kopello, Carex bogs, Rwenzori Mountains, $00^{\circ} 18.612^{\prime}$ N, $29^{\circ} 53.504^{\prime}$ S, 4054 m.a.s.1..

\section{Distribution}

Flavalona sphagnophila comb. nov. appears to be endemic to the Rwenzori mountains. It inhabits the Carex-Sphagnum bogs surrounding lakes Kopello (4017 m.a.s.1.) and Nsuranja (3834 m.a.s.l), but not the littoral of these lakes (Van Damme \& Eggermont 2011).

\section{Discussion}

The generic status of Flavalona gen. nov. is justified by at least two autapomorphies, viz. elongated lateral head pores with pocket-like cavities, and a male postabdomen with a genital process. Within Aloninae, pores with cavities are present in Ovalona nigra (Smirnov, 1996) and Camptocercus australis Baird, 1843 (see Sinev 2015a, 2015b), but in both these species they are small and spherical. Other species of Ovalona and Camptocercus Sars, 1896 have normal, alonine dot-like lateral pores. Genital process of male postabdomen is present in genera Leydigia and Armatalona, both quite remote from Alona s. lato (see Kotov 2009; Sinev 2004).

Like other recently established genera of Alona s.l., Flavalona gen. nov. is uniform in the morphology of the thoracic limbs, which is a criterion for generic status within the group. It differs from the affinisand intermedia-groups of Hexalona by a weakly developed IDL seta 1 of limb I, seta i of limb I with reduced distal part, and by differentiated flaming-torch setae of limb IV. In limb morphology, Flavalona gen. nov. is similar to the guttata-group, and both might well be sister-groups. Synapomorphies of Flavalona gen. nov. and the guttata-group include reduced IDL seta 1 of limb I, differentiated flaming- 
torch setae of limb IV and weakly-developed lateral fascicles of postabdominal setules, with distalmost setae not much thicker than others, as common for all other Alona s.l. The guttata-group, which should probably be given generic status as well, have minute lateral head pores and lack genital process от male postabdomen. Species of the guttata-group also clearly differ from Flavalona gen. nov. by the morphology of the female postabdomen, which is shorter and wider, and has a prominent preanal angle. The guttata-group also has one distinctive autapomorphy in limb morphology, viz. the fully reduced seta i of limb I (see Sinev 1999b; Sinev \& Silva-Briano 2012), which is present in Flavalona gen. nov. The sister status of Flavalona gen. nov. and guttata-group is also supported by DNA data. In trees produced by Sacherova \& Hebert (2003), Flavalona costata comb. nov. and Alona guttata Sars, 1862 form a clade, which does not group with Alona affinis (Leydig, 1860), the only other Hexalona species analyzed in their work.

While Flavalona gen. nov. and the guttata-group thus form a monophyletic clade, their affinities with other groups are unclear. Their unique synapomorphy, the differentiated flaming-torch setae of limb IV is not shared by any other Alona s.l., and their similarities with other groups of Hexalona, such as the affinis and intermedia groups, include only plesiomorphic characters.

The genus is clearly separated into two lineages, the costata- and the rustica-clades. These groups differ in sculpture and ventral setae of the valves, morphology of lateral head pores, shape and armament of female postabdomen, and morphology of male postabdomen. In contrast, there are no significant differences between them in morphology of appendages.

The species-richness of the group appears still to be underestimated. Flössner \& Frey (1970) did not find differences between Eurasian and American F. costata comb. nov., and assigned Nearctic F. rustica s.l. comb. nov. to subspecies status. But they did not study the morphology of the appendages and of the head pores. The North American F. costata s.l. comb. nov. may belong to a separate species, and North American F. rustica s.l. comb. nov. may include populations differing in limb morphology from each other and from F. rustica rustica comb. nov.. Two taxa of Flavalona gen. nov. from Greenland, described by Røen (1992) as Alona fabricii Røen, 1992 and A. muelleri Røen, 1992 were sunk in the synonymy of F. rustica comb. nov. and F. costata comb. nov. by Van Damme et al. (2010), but in view of the unsettled situation in North American Flavalona gen. nov., these taxa need to be restudied.

The taxonomic status of Flavalona gen. nov. in sub-sahelian Africa remains questionable. Moreover, Alona virago Brehm, 1935 from China, is morphologically similar to species of the costata-clade. Its postabdomen is similar to that of $F$. weltneri comb. nov. (see Chiang \& Du 1979), but its head pores and appendages are unknown.

Flavalona gen. nov. is distributed worldwide, but is more successful in temperate regions of the northern hemisphere. Flavalona costata s.l. comb. nov. is a one of the common alonines in the Palearctic and Nearctic regions. Flavalona rustica americana s.l. comb. nov. is common in the Nearctic, and F. rustica rustica comb. nov. is widely distributed in Europe and Siberia. Two more taxa with a limited distribution, $F$. weltneri comb. nov. and F. bicolor comb. nov., are confined to temperate regions as well. In contrast, even widely distributed tropical species, F. cheni comb. nov., F. iheringula comb. nov., F. margipluma comb. nov. and F. setigera comb. nov., as well as African populations of Flavalona gen. nov., appear to be rare.

The rustica-clade, while more species-rich, is obviously less successful than the costata-clade. Most species of the group (F. rustica americana s.1. comb. nov., F. bicolor comb. nov., F. iheringula comb. nov. and $F$. hudeci comb. nov.) occur in America. Flavalona rustica americana s.l. comb. nov. is wide-ranging, but all other American species have limited ranges. In the Old World the rustica-clade is represented by only two species, of which $F$. sphagnophila comb. nov. is a mountain endemic and $F$. rustica rustica 
comb. nov., while widely distributed in the West Palearctic, is confined to dystrophic sphagnum bogs in coniferous forests and mountain belts. Species of the rustica-clade have never been recorded in China (Chiang \& Du 1979; Ji et al. 2015), South-East Asia (Korovchinsky 2013), India (Chatterjee et al. 2013) or Australia (Smirnov \& Timms 1983). In contrast, the costata-clade is distributed worldwide, and includes at least four wide-ranging species: Palearctic F. costata s.s. comb. nov., North American F. costata s.l. comb. nov., tropical Asian F. cheni comb. nov. and Australian F. setigera comb. nov. Two species have more limited ranges (F. margipluma comb. nov. and $F$. weltneri comb. nov.) and two are mountain endemics (F. hudeci comb. nov. and F. natalensis comb. nov.).

The distribution of Flavalona gen. nov. is similar to that of Ovalona. About half of the species in both genera are mountain endemics and species with a limited distribution. The less successful setulosaclade of Ovalona and rustica-clade of Flavalona mostly occurs in the New World and is absent in tropical Asia and Australia; species of the setulosa-clade are not present in Africa either, while the only African species of the rustica-clade, F. sphagnophila comb. nov., is a mountain endemic. In contrast, the evolutionary advanced Ovalona cambouei-clade is distributed on all continents. The most widely distributed species, Neotropical O. glabra (Sars, 1901), Palaeaotropical O. cambouei (Guerne \& Richard, 1893) and Australian O. pulchella (King, 1853), are similar morphologically. The costataclade of Flavalona gen. nov. is also cosmopolitan, and is much more morphologically uniform than the rustica-clade.

\section{Acknowledgments}

We are grateful to Yang Liang Gu (Jinan University, Guangzhou), Thomas Jensen and Bjorn Walseng (Norwegian Institute for Nature Research, Oslo) for assistance during sampling trips, and to Prof. Nikolai N. Smirnov (A.N. Severtsov Institute of Ecology and Evolution, Moscow) for material and valuable comments. Collecting of material in Eurasia and its morphological studies were conducted solely by the first author under support by the Russian Science Foundation grant 14-14-00778. Efforts of the second author were supported by the Chinese National Programs for Fundamental Research and Development (973 Program, No. 2012CB956104) and by grant for leading talent scientists of the Guangdong Province to Henri Dumont.

\section{References}

Alonso M. 1996. Crustacea, Branchiopoda. Fauna Iberica 7. Museo National de Ciencias Natural. Consejo Superior de Investigationes Cientificas, Madrid.

Behning A.L. 1941. The Cladocerans of the Caucasus. Gruzmedgiz Publishing, Tbilisi. [In Russian]

Brehm V. 1931. Cladoceren aus Neuseeland. Archiv für Hydrobiologie 23: 491-501

Chatterjee T., Kotov A.A., Van Damme K., Chandrasekhar S.V.A. \& Padhye S. 2013. An annotated checklist of the Cladocera (Crustacea: Branchiopoda) from India. Zootaxa 3667 (1): 1-89. http://dx.doi. org/10.11646/zootaxa.3667.1.1

Chen S.Z. \& Peng J.H. 1993. Three new records of Cladocera (Crustacea: Diplostraca) from China. Sichuan Journal of Zoology 12 (4): 19-21. [in Chinese]

Chengalath R. 1982. A faunistic and ecological survey of the littoral Cladocera of Canada. Canadian Journal of Zoology 60 (11): 2668-2682. http://dx.doi.org/10.1139/z82-343

Chengalath R. 1987. The distribution of chydorid Cladocera in Canada. Hydrobiologia 145 (1): 151157. http://dx.doi.org/10.1007/BF02530275

Chiang S. \& Du N. 1979. Fauna Sinica. Crustacea. Freshwater Cladocera. Science Press, Academia Sinica, Peking. 
Dumont H.J. 1983. Discovery of groundwater inhabiting Chydoridae (Crustacea: Cladocera), with the description of two new species. Hydrobiologia 106: 97-106. http://dx.doi.org/10.1007/BF00006741

Dumont H.J. \& Silva-Briano M. 2000. Karualona gen. nov. (Anomopoda: Chydoridae), with a description of two new species, and a key to all known species. Hydrobiologia 435: 61-82. http://dx.doi. org/10.1023/A:1004006521874

Elmoor-Loureiro L.M.A. 2015. Cladóceros do Brasil: Famílias Chydoridae e Eurycercidae. Available from https://cladocera.wordpress.com/ [accessed 4 Aug. 2016]

Flössner D. 1967. Alona rustica Scott und Alona costata Sars (Cladocera, Chydoridae). Zur Kenntnis der Morphologie und Okologie einer Zwillingsart. Limnologica 5 (3): 417- 434.

Flössner D. 1972. Die Tierwelt Deutschlands. Krebstiere, Crustacea (Kiemen- und Blattfüsser. Branchiopoda, Fischläuse, Branchiura). Gustav Fischer Verlag, Jena.

Flössner D. 2000. Die Haplopoda und Cladocera (ohne Bosminidae) Mitteleuropas. Backhuys Publishers, Leiden.

Flössner D. \& Frey D.G. 1970. A morphological comparison of European and North American populations of Alona rustica Sars and Alona costata Scott (Cladocera, Chydoridae). Limnologica 7: 325-337.

Frey D.G. 1965. Differentiation of Alona costata Sars from two related species (Cladocera, Chydoridae). Crustaceana 8: 159-173.

Frey D. G. 1967. Phylogenetic relationships in the family Chydoridae (Cladocera). Proceedings of Symposium on Crustacea. Marine Biology Association of India. 12-15 Januaty 1965, Ernakulam. Part 1: $29-37$.

Frey, D. G., 1969. Further notes on Alona bicolor Frey, 1965 (Cladocera, Chydoridae), with a description of the male. Transactions of the American Microscopical Society 88: 380-386.

Hellich B. 1877. Die Cladoceren Böhmens. Archiv für die Naturwissenschaftliche Landesdurchforschung von Böhmen 3: 1-131.

Herbst H.V. 1962. Blattfusskrebse (Phyllopoden: Echte Blattfüsser und Wasserflöhe). Kosmos, Stuttgart.

Hudeč I. 1998. Anomopoda (Crustacea: Branchiopoda) from some Venezuelan tepuis. Hydrobiologia 377: 205-211. http://dx.doi.org/10.1023/A:1003260602055

Hudeč I. 2010. Fauna Slovenska III. Anomopoda, Ctenopoda, Haplopoda, Onychopoda (Crustacea: Branchiopoda).Veda, Bratislava.

Idris B.A.G. 1983. Freshwater Zooplankton of Malaysia (Crustacea: Cladocera). Penerbit Universiti Pertanian Malaysia. Syarikat Percetakan Selangor, Kuala Lumpur.

Ji G.H., Xiang X.F., Chen S.Z., Yu G.L., Kotov A.A. \& Dumont H.J. 2015. Annotated Checklist of Chinese Cladocera (Crustacea: Branchiopoda). Part II. Order Anomopoda (families Macrotrichidae, Eurycercidae and Chydoridae). Zootaxa 4044 (2): 241-269. http://dx.doi.org/10.11646/zootaxa.4044.2.4

Keilhack L. 1905. Zur Cladocerenfauna des Madüsees in Pommern. Beiträge zur Fauna des Madüsees in Pommern. Von Dr. M. Samter und Dr. W. Weltner. Erste Mitteilung. Archiv für Naturgeschichte 71: 138-162. Available from http://biodiversitylibrary.org/page/15074007 [accessed 28 Jul. 2016]

Keilhack L. 1908. Zür Cladocerenfauna der Mark Brandenburg. Mitteilungen aus dem Zoologischen Museum in Berlin III (4): 435-488. 
Korovchinsky N.M. 2013. Cladocera (Crustacea: Branchiopoda) of South East Asia: history of explorations, taxon richness and notes on zoogeography. Journal of Limnology 72 (S2): 109-124. http:// dx.doi.org/10.4081/jlimnol.2013.s2.e7

Kotov A.A. 2000. Redescription and assignment of the chydorid Indialona ganapati Petkovski, 1966 (Branchiopoda: Anomopoda: Aloninae) to Indialonini, new tribus. Hydrobiologia 439: 161-178. http:// dx.doi.org/10.1023/A:1004187007890

Kotov A.A. 2009. A revision of Leydigia Kurz, 1875 (Anomopoda, Cladocera, Branchiopoda), and subgeneric differentiation within the genus. Zootaxa 2082: 1-84.

Kotov A.A. \& Sinev A.Y. 2004. Notes on Aloninae Dybowski \& Grochowski, 1894 emend. Frey, 1967 (Cladocera: Anomopoda: Chydoridae): 3. Alona iheringula nom. nov. instead of A. iheringi Sars, 1901, with comments on this taxon. Arthropoda Selecta 13: 95-98.

Kotov A.A., Sinev A.Y. \& Berrios V.L. 2010. The Cladocera (Crustacea: Branchiopoda) of six high altitude water bodies in the North Chilean Andes, with discussion of Andean endemism. Zootaxa 2430: $1-66$.

Lilljeborg W. 1901. Cladocera Sueciae. Nova acta regiae societatis scientatis scientiarum upsaliensis, seriei tertiae 19, Royal Society of Sciences, Upsala. Available from http://biodiversitylibrary.org/ page/14534518 [accessed 28 Jul. 2016]

Maëmets A. 1958. Sustemaatilis-okoloogilisi andmeid moningate huvitavate Eesti vesikirbuliste (Cladocera) kohta. Eesti NSV Teaduste Akadeemia Toimetised (Bioloogia) 7 (4): 260-271.

Maëmets A. 1960. Täiendavaid andmeid vesikirbuliste (Cladocera) liigi Alona estonica kohta. Eesti NSV Teaduste Akadeemia Toimetised (Bioloogia) 1: 35-45.

Maiphae S., Pholpunthin P. \& Dumont H.G. 2008. Taxon richness and biogeography of the Cladocera (Crustacea: Ctenopoda, Anomopoda) of Thailand. International Journal of Limnology 44 (1): 33-43. http://dx.doi.org/10.1051/limn:2008021

Margaritora F.G. 1985. Cladocera. Fauna d'Italia XXIII. Calderini, Bologna.

Margaritora F.G. \& Vagaggini D. 2002. Two Chydoridae species (Crustacea, Cladocera) new to Italy: Alona rustica and Camptocercus uncinatus. Italian Journal of Zoology 69: 59-63. http://dx.doi. org/10.1080/11250000209356439

Müller P.E. 1867. Danmarks Cladocera. Naturhistorisk tidsskrift 3: 53-240.

Negrea S. 1983. Cladocera. Fauna Republicii Socialiste Romania, Crustacea 4. Bucureşti.

Norman A.M. \& Brady G.S. 1867. A monograph of the British Entomostraca belonging to the families Bosminidae, Macrothricidae and Lynceidae. Natural History Transactions of Northumberland and Durham 1: 354-408.

Røen U. 1992. Review of Greenlandic species of Alona Baird, 1850,with descriptions of three new species (Cladocera: Chydoridae: Aloninae). Steenstrupia 18: 101-109.

Sacherova V. \& Hebert P. D. 2003. The evolutionary history of the Chydoridae (Crustacea: Cladocera). Biological Journal of the Linnean Society 79 (4): 629-643. http://dx.doi.org/10.1046/j.1095$\underline{8312.2003 .00216 . \mathrm{x}}$

Sabater F. 1987. On the interstitial Cladocera of the River Ter (Catalonia, NE Spain), with a description of the male of Alona phreatica. Hydrobiologia 144: 61-62. http://dx.doi.org/10.1007/BF00008051 
Santos-Wisniewsky M.J., Rocha O. \& Matsumura-Tundisi, T. 2001. First record of Alona setigera Brehm (Cladocera, Chydoridae) in the Neotropical region. Brazilian Journal of Biology 61: 701-702. http://dx.doi.org/10.1590/S1519-69842001000400022

Sars G.O. 1862. Hr. studios. Medic. G.O. Sars fortsatte sit Foredrag over de af ham i Omegnen af Christiania iagttagne Crustacea cladocera. Forhandlinger $i$ Videnskabs-Selskabet $i$ Christiania 1861: 250-302.

Sars G.O. 1901. Contributions to the knowledge of the freshwater Entomostraca of South America, as shown by artificial hatching from dried material. 1. Cladocera. Archivfor Mathematik og Naturvidenskab Christiania 23: 1-102.

Sars G.O. 1993. On the freshwater crustaceans occurring in the vicinity of Christiania. Christiansen M.E. et al. (eds), University of Bergen Press, Bergen.

Schoedler E. 1862. Die Lynceiden und Polyphemiden der Umgegend von Berlin. Jahresberichte über die Dorotheenstädtische Realschule 1862, Dorotheenstädtische Realschule, Berlin.

Scott T. 1895. The inland waters of the Shetland Islands. Notes on the species represented by the drawings on Plate V. Annual Report of the Fishery Board of Scotland 13: 189-191.

Silva E.S., Abreu C.B., Orlando T.C., Wisniewski C. \& Santos-Wisniewski M.J. 2014. Alona iheringula Sinev \& Kotov, 2004 (Crustacea, Anomopoda, Chydoridae, Aloninae): Life Cycle and DNA Barcode with Implications for the Taxonomy of the Aloninae Subfamily. Plos One 9: e97050. http://dx.doi. org/10.1371/journal.pone.0097050

Sinev A.Y. 1999a. Alona costata Sars, 1862 versus related palaeotropical species: the first example of close relations between species with a different number of main head pores among Chydoridae (Crustacea: Anomopoda). Arthropoda Selecta 8: 131-148.

Sinev A.Y. 1999b. Alona werestschagini sp. n., new species of genus Alona Baird, 1843, related to A. guttata Sars, 1862 (Anomopoda, Chydoridae). Arthropoda Selecta 8: 23-30.

Sinev A.Y. 2001. Redescription of Alona iheringi Sars, 1901 (Chydoridae, Anomopoda, Branchiopoda), a South American species related to A. rustica Scott, 1895. Hydrobiologia 464: 113-119. http://dx.doi. org/10.1023/A:1013935100483

Sinev A.Y. 2002. A key to identifying cladocerans of the genus Alona (Anomopoda, Chydoridae) from the Russian European part and Siberia. Zoologychesky zhurnal 81: 926-939.

Sinev A.Y. 2004. Armatalona gen. nov. - a new genus of subfamily Aloninae (Anomopoda, Chydoridae), separated from genus Alona Baird, 1840. Hydrobiologia 420: 29-47. http://dx.doi.org/10.1023/ B:HYDR.0000027723.38965.11

Sinev A.Y. 2008. A new species related to Alona costata Sars, 1862 (Cladocera: Anomopoda: Chydoridae) from South Africa. Zootaxa 1707: 23-36.

Sinev A.Y. 2009. Notes on morphology and taxonomic status of some North American species of the genus Alona Baird, 1843 (Cladocera: Anomopoda: Chydoridae). Fundamental and Applied Limnology - Archiv fur Hydrobiologie 175: 59-77. http://dx.doi.org/10.1127/1863-9135/2009/0175-0059

Sinev A.Y. 2012. Alona kotovi sp. nov., a new species of Aloninae (Cladocera: Anomopoda: Chydoridae) from South Vietnam. Zootaxa 3475: 45-54.

Sinev A.Y. 2015a. Morphology and phylogenetic position of three species of genus Camptocercus Baird, 1843 (Cladocera: Anomopoda: Chydoridae). Zootaxa 4040 (2): 169-186. http://dx.doi.org/10.11646/ zootaxa.4040.2.4 
Sinev A.Y. 2015b. Revision of the pulchella-group of Alona s. lato leads to its translocation to Ovalona Van Damme \& Dumont, 2008 (Branchiopoda: Anomopoda: Chydoridae). Zootaxa 4044 (4): 451-492. http://dx.doi.org/10.11646/zootaxa.4044.4.1

Sinev A.Y. \& Kotov A.A. 2012. New and rare Aloninae (Cladocera: Anomopoda: Chydoridae) from Indochina. Zootaxa 3334: 1-28.

Sinev A.Y. \& Shiel R.J. 2008. Redescription of Alona macracantha Smirnov and Timms, 1983 and its assignment to Maraura gen. nov. (Cladocera: Anomopoda: Chydoridae). Journal of Natural History 42 (45-46): 2809-2824. http://dx.doi.org/10.1080/00222930802361048

Sinev A.Y. \& Silva-Briano M. 2012. Cladocerans of the genus Alona Baird, 1843 (Cladocera: Anomopoda: Chydoridae) and related genera from Aguascalientes State, Mexico. Zootaxa 3569: 1-24.

Sinev A.Y., Gu Y. \& Han B. 2015. Cladocera of Hainan Island, China. Zootaxa 4006 (3): 569-585. http://dx.doi.org/10.11646/zootaxa.4006.3.9

Sinev A.Y., Van Damme K. \& Kotov A.A. 2005. Redescription of tropical-temperate cladocerans Alona diaphana King, 1853 and Alona davidi Richard, 1895 and their translocation to Leberis Smirnov 1989 (Branchiopoda: Anomopoda: Chydoridae). Arthropoda Selecta 14: 183-205.

Smirnov N.N. 1971. Chydoridae fauny mira. Fauna USSR. Rakoobraznie, 1(2). Leningrad. (English translation: Chydoridae of the world. Israel Program for Scientific Translations, Jerusalem, 1974).

Smirnov N.N. \& Timms B. 1983. A revision of the Australian Cladocera. Records of the Australian Museum, Supplement 1, The Australian Museum, Sydney.

Sousa F.D.R., Santos S., Güntzel A.M., Diniz L.P., de Melo Junior M. \& Elmoor-Loureiro L.M.A. 2015. Description of a new species of the costata-group (Cladocera, Chydoridae, Aloninae) from Brazil. Zootaxa 4040 (4): 445-457. http://dx.doi.org/10.11646/zootaxa.4040.4.4

Šrámek-Hušek R., Strašcraba M. \& Brtek J. 1962. Lupenonožci-Branchiopoda. Fauna ČSSR, 16. Praha.

Stuckenberg B. 1969. Effective temperature as an ecological factor in Southern Africa. Zoologica Africana 4: 145-197. http://dx.doi.org/10.1080/00445096.1969.11447371

Van Damme K. \& Dumont H. J. 2008a. Further division of Alona Baird, 1843: separation and position of Coronatella Dybowski \& Grochowski and Ovalona gen.n. (Crustacea: Cladocera). Zootaxa 1960: 1-44.

Van Damme K. \& Dumont H. J. 2008b. The 'true' genus Alona Baird, 1843 (Crustacea: Cladocera: Anomopoda): characters of the A. quadrangularis-group and description of a new species from Democratic Republic Congo. Zootaxa 1943: 1-25.

Van Damme K. \& Dumont H. J. 2009. Notes on chydorid endemism in continental Africa: Matralona gen. nov., a monotypic Alonine from the Fouta Djalon Plateau (Guinea, West Africa) (Crustacea: Cladocera: Anomopoda). Zootaxa 2051: 26-40.

Van Damme K. \& Dumont H.J. 2010. Cladocera of the Lençóis Maranhenses (NE-Brazil): faunal composition and a reappraisal of Sars' Method. Brazilian Journal of Biology 70 (3): 755-779.

Van Damme K. \& Eggermont H. 2011. The Afromontane Cladocera (Crustacea: Branchiopoda) of the Rwenzori (Uganda-D. R. Congo): taxonomy, ecology and biogeography. Hydrobiologia 675: 57-100. http://dx.doi.org/10.1007/s10750-011-0892-0

Van Damme K. \& Maiphae S. 2013. Salinalona gen. nov., an euryhaline chydorid lineage (Crustacea: Branchiopoda: Cladocera: Anomopoda) from the Oriental region. Journal of Limnology 72 (S2): 142173. http://dx.doi.org/10.4081/jlimnol.2013.s2.e9 
Van Damme K. \& Sinev A.Y. 2011. A new genus of cave-dwelling microcrustaceans from the Dinaric Region (south-east Europe): adaptations of true stygobitic Cladocera (Crustacea: Branchiopoda). Zoological Journal of the Linnean Society 161: 31-52. http://dx.doi.org/10.1111/j.1096$\underline{3642.2010 .00639 . \mathrm{x}}$

Van Damme K., Bekker E.I. \& Kotov A.A. 2013. Endemism in the Cladocera (Crustacea: Branchiopoda) of Southern Africa. Journal of Limnology 72 (3): 440-463. http://dx.doi.org/10.4081/jlimnol.2013.e36

Van Damme K., Brancelj A. \& Dumont H.J. 2009. Adaptations to the hyporheic in Aloninae (Crustacea: Cladocera): allocation of Alona protzi Hartwig, 1900 and related species to Phreatalona gen. nov. Hydrobiologia 618: 1-34. http://dx.doi.org/10.1007/s10750-008-9607-6

Van Damme K., Elias-Gutierrez M. \& Dumont H.J. 2011. Three rare European "Alona" taxa (Branchiopoda: Cladocera: Chydoridae), with notes on distribution and taxonomy. International Journal of Limnology 47: 45-63. http://dx.doi.org/10.1051/limn/2010034

Van Damme K., Kotov A.A. \& Dumont H.J. 2010. A checklist of names in Alona Baird 1843 (Crustacea: Cladocera: Chydoridae) and their current status: an analysis of the taxonomy of a lump genus. Zootaxa 2330: $1-63$.

Van de Velde I. \& Dumont H.J. 1978. Liste des espèces de Cladocères connues aux îles des Açores. Bulletin du Museum national d' Histoire naturelle de Paris 3e serie, 515, Zoologie 354: 355-365.

Manuscript received: 15 February 2016

Manuscript accepted: 24 March 2016

Published on: 18 August 2016

Topic editor: Rudy Jocqué

Desk editor: Kristiaan Hoedemakers

Printed versions of all papers are also deposited in the libraries of the institutes that are members of the EJT consortium: Muséum national d'Histoire naturelle, Paris, France; Botanic Garden Meise, Belgium; Royal Museum for Central Africa, Tervuren, Belgium; Natural History Museum, London, United Kingdom; Royal Belgian Institute of Natural Sciences, Brussels, Belgium; Natural History Museum of Denmark, Copenhagen, Denmark; Naturalis Biodiversity Center, Leiden, the Netherlands. 